\title{
Elemental ratio measurements of organic compounds using aerosol mass spectrometry: characterization, improved calibration, and implications
}

\author{
M. R. Canagaratna ${ }^{1}$, J. L. Jimenez ${ }^{2}$, J. H. Kroll ${ }^{3,4}$, Q. Chen ${ }^{3}$, S. H. Kessler ${ }^{4}$, P. Massoli ${ }^{1}$, L. Hildebrandt Ruiz ${ }^{5}$, \\ E. Fortner ${ }^{1}$, L. R. Williams ${ }^{1}$, K. R. Wilson ${ }^{6}$, J. D. Surratt ${ }^{7}$, N. M. Donahue ${ }^{8}$, J. T. Jayne ${ }^{1}$, and D. R. Worsnop ${ }^{1}$ \\ ${ }^{1}$ Aerodyne Research, Inc., Billerica, MA, USA \\ ${ }^{2}$ Department of Chemistry and Biochemistry, and Cooperative Institute for Research in the Environmental Sciences (CIRES), \\ University of Colorado, Boulder, CO, USA \\ ${ }^{3}$ Department of Civil and Environmental Engineering, Massachusetts Institute of Technology, Cambridge, MA, USA \\ ${ }^{4}$ Department of Chemical Engineering, Massachusetts Institute of Technology, Cambridge, MA, USA \\ ${ }^{5}$ McKetta Department of Chemical Engineering, and Center for Energy and Environmental Resources, The University of \\ Texas at Austin, Austin, TX, USA \\ ${ }^{6}$ Lawrence Berkeley National Lab, Berkeley, CA, USA \\ ${ }^{7}$ Department of Environmental Science and Engineering, University of North Carolina, Chapel Hill, NC, USA \\ ${ }^{8}$ Center for Atmospheric Particle Studies, Carnegie Mellon University, Pittsburgh, PA, USA
}

Correspondence to: M. R. Canagaratna (mrcana@aerodyne.com)

Received: 27 June 2014 - Published in Atmos. Chem. Phys. Discuss.: 31 July 2014

Revised: 17 November 2014 - Accepted: 25 November 2014 - Published: 12 January 2015

\begin{abstract}
Elemental compositions of organic aerosol (OA) particles provide useful constraints on OA sources, chemical evolution, and effects. The Aerodyne high-resolution time-of-flight aerosol mass spectrometer (HR-ToF-AMS) is widely used to measure OA elemental composition. This study evaluates AMS measurements of atomic oxygento-carbon $(\mathrm{O}: \mathrm{C})$, hydrogen-to-carbon $(\mathrm{H}: \mathrm{C})$, and organic mass-to-organic carbon (OM : OC) ratios, and of carbon oxidation state $\left(\overline{\mathrm{OS}}_{\mathrm{C}}\right)$ for a vastly expanded laboratory data set of multifunctional oxidized OA standards. For the expanded standard data set, the method introduced by Aiken et al. (2008), which uses experimentally measured ion intensities at all ions to determine elemental ratios (referred to here as "Aiken-Explicit"), reproduces known $\mathrm{O}: \mathrm{C}$ and $\mathrm{H}: \mathrm{C}$ ratio values within $20 \%$ (average absolute value of relative errors) and $12 \%$, respectively. The more commonly used method, which uses empirically estimated $\mathrm{H}_{2} \mathrm{O}^{+}$and $\mathrm{CO}^{+}$ion intensities to avoid gas phase air interferences at these ions (referred to here as "Aiken-Ambient"), reproduces $\mathrm{O}: \mathrm{C}$ and $\mathrm{H}: \mathrm{C}$ of multifunctional oxidized species within 28 and $14 \%$ of known values. The values from the latter method are sys-
\end{abstract}

tematically biased low, however, with larger biases observed for alcohols and simple diacids. A detailed examination of the $\mathrm{H}_{2} \mathrm{O}^{+}, \mathrm{CO}^{+}$, and $\mathrm{CO}_{2}^{+}$fragments in the high-resolution mass spectra of the standard compounds indicates that the Aiken-Ambient method underestimates the $\mathrm{CO}^{+}$and especially $\mathrm{H}_{2} \mathrm{O}^{+}$produced from many oxidized species. Combined AMS-vacuum ultraviolet (VUV) ionization measurements indicate that these ions are produced by dehydration and decarboxylation on the AMS vaporizer (usually operated at $600^{\circ} \mathrm{C}$ ). Thermal decomposition is observed to be efficient at vaporizer temperatures down to $200{ }^{\circ} \mathrm{C}$. These results are used together to develop an "Improved-Ambient" elemental analysis method for AMS spectra measured in air. The Improved-Ambient method uses specific ion fragments as markers to correct for molecular functionality-dependent systematic biases and reproduces known $\mathrm{O}: \mathrm{C}(\mathrm{H}: \mathrm{C})$ ratios of individual oxidized standards within $28 \%(13 \%)$ of the known molecular values. The error in Improved-Ambient $\mathrm{O}: \mathrm{C}(\mathrm{H}: \mathrm{C})$ values is smaller for theoretical standard mixtures of the oxidized organic standards, which are more representative of the complex mix of species present in ambient 
OA. For ambient OA, the Improved-Ambient method produces $\mathrm{O}: \mathrm{C}(\mathrm{H}: \mathrm{C})$ values that are $27 \%(11 \%)$ larger than previously published Aiken-Ambient values; a corresponding increase of $9 \%$ is observed for $\mathrm{OM}$ : $\mathrm{OC}$ values. These results imply that ambient $\mathrm{OA}$ has a higher relative oxygen content than previously estimated. The $\overline{\mathrm{OS}}_{\mathrm{C}}$ values calculated for ambient OA by the two methods agree well, however (average relative difference of $0.06 \overline{\mathrm{OS}}_{\mathrm{C}}$ units). This indicates that $\overline{\mathrm{OS}}_{\mathrm{C}}$ is a more robust metric of oxidation than $\mathrm{O}: \mathrm{C}$, likely since $\overline{\mathrm{OS}}_{\mathrm{C}}$ is not affected by hydration or dehydration, either in the atmosphere or during analysis.

\section{Introduction}

Organic aerosols (OA) account for a substantial fraction of ambient submicron aerosol mass in urban and rural/remote environments, with important impacts ranging from human health to climate forcing (IPCC, 2013; Pope and Dockery, 2006). In recent years the Aerodyne aerosol mass spectrometers (AMS; Canagaratna et al., 2007) have seen wide use for characterizing the composition, the elemental ratios $(\mathrm{H}: \mathrm{C}$, $\mathrm{O}: \mathrm{C}, \mathrm{N}: \mathrm{C}, \mathrm{S}: \mathrm{C}, \mathrm{OM}: \mathrm{OC}$ ) (Aiken et al., 2007, 2008) and the approximate carbon oxidation state $\left(\overline{\mathrm{OS}}_{\mathrm{C}} \approx 2 \times \mathrm{O}: \mathrm{C}\right.$ $\mathrm{H}: \mathrm{C}$ ) of OA (Kroll et al., 2011). This information provides key constraints for understanding aerosol sources, processes, impacts, and fate, and for experimentally constraining and developing predictive aerosol models on local, regional, and global scales.

Organic aerosol elemental ratios can be measured with a number of analytical techniques besides the AMS. These include combustion analysis (O'Brien et al., 1975; Krivacsy et al., 2001; Kiss et al., 2002), electrospray ionization coupled to ultra-high-resolution mass spectrometry with (ESI) (Nguyen and Schug, 2008; Altieri et al., 2009; Bateman et al., 2009; Kroll et al., 2011; Mazzoleni et al., 2010), nuclear magnetic resonance (NMR) spectroscopy (Fuzzi et al., 2001), Fourier transform infrared spectroscopy (FTIR) (Gilardoni et al., 2009; Mysak et al., 2011), and X-ray photoelectron spectroscopy (XPS) (Mysak et al., 2011). Gas chromatography-mass spectrometry (GCMS) (Williams et al., 2006) and chemical ionization mass spectrometry (CIMS) with aerosol collection interface have also recently been coupled to a high-resolution time-of-flight mass spectrometer to allow for determination of elemental ratios (i.e., O: $\mathrm{C}$ and $\mathrm{H}: \mathrm{C}$ ) of organic aerosols (LopezHilfiker et al., 2014; Yatavelli and Thornton, 2010; Williams et al., 2014). Each of these techniques has its own strengths and weaknesses. AMS measurements of bulk aerosol elemental composition are obtained directly from the average elemental compositions of the individual fragment ions observed in high-resolution AMS spectra. One strength of the AMS approach is that it offers the capability of online, sensitive detection of aerosol elemental composition. A weakness is its use of empirical corrections that can affect the accuracy of the calculated elemental ratios. This manuscript evaluates the accuracy of the AMS elemental analysis approach over a wider range of OA species than has been studied before.

In the AMS, aerosol particles are focused into a beam in a high-vacuum chamber and typically flash-vaporized on a tungsten vaporizer at a temperature of $600^{\circ} \mathrm{C}$ before constituents are detected with electron ionization (EI) mass spectrometry. Thus, the elemental composition obtained from AMS mass spectra can be potentially biased by two sources: vaporization and ion fragmentation. Organic molecules, particularly oxidized organic species comprising oxidized organic aerosol (OOA), can decompose during the AMS vaporization process to form stable molecules with elemental compositions that differ from the original parent molecule. Carboxylic acids and alcohols, for example, are known to undergo thermally induced dehydration and decarboxylation as follows (Moldoveanu, 2009):

$\mathrm{RCOOH} \longrightarrow{ }^{\Delta} \mathrm{CO}_{2}+\mathrm{H}_{2} \mathrm{O}+\mathrm{CO}+\mathrm{R}^{\prime}$

$\mathrm{RCOH} \longrightarrow{ }^{\Delta} \mathrm{H}_{2} \mathrm{O}+\mathrm{R}^{\prime}$

The decomposition products are all ionized and detected by the AMS. The loss of neutral $\mathrm{CO}_{2}, \mathrm{CO}$, and $\mathrm{H}_{2} \mathrm{O}$ from the parent carboxylic acid and alcohol molecules results in the formation of organic ions in EI ( $\mathrm{R}^{\prime+}$ and their fragments) that differ significantly from their parents in chemical identity and elemental composition. The accuracy with which the parent elemental ratios are calculated from AMS measurements will depend on the accuracy with which the $\mathrm{C}, \mathrm{H}$, and $\mathrm{O}$ masses in all of the decomposition fragments are measured or accounted for. Mass spectral interferences from gas and particle species further complicate accurate determinations of $\mathrm{H}_{2} \mathrm{O}^{+}$and $\mathrm{CO}^{+}$intensities for OA sampled in air (Aiken et al., 2008).

Previous work by Aiken et al. $(2007,2008)$ showed that $\mathrm{O}: \mathrm{C}$ and $\mathrm{H}: \mathrm{C}$ ratios of laboratory standard molecules can be estimated to within 31 and $10 \%$ (average absolute value of the relative error, respectively) with the AMS. The "AikenExplicit" (A-E) method averages the elemental composition of all measured fragment ions observed in high-resolution mass spectra and uses $\mathrm{H}: \mathrm{C}$ and $\mathrm{O}: \mathrm{C}$ calibration factors derived from laboratory measurements of standard organic molecules. The calibration factors account for differences between the elemental compositions of the detected fragment ions and their parent molecules, e.g., due to the tendency of more electronegative fragments with high $\mathrm{O}$ content to end up as neutrals rather than as positive ions during the ion fragmentation process. The "Aiken-Ambient" (A-A) method is similar; however, it uses empirically estimated $\mathrm{H}_{2} \mathrm{O}^{+}$and $\mathrm{CO}^{+}$intensities for OA sampled in air. The Aiken-Ambient method is widely used for elemental analysis of ambient and 
chamber OA because the intensities of $\mathrm{H}_{2} \mathrm{O}^{+}$and $\mathrm{CO}^{+}$originating from $\mathrm{OA}$ are difficult to separate from those originating from other background species in air.

In this study we extend the Aiken et al. $(2007,2008)$ elemental analysis calibrations to a wider range of OA species. The Aiken et al. $(2007,2008)$ calibration data set used consisted of reduced primary OA (POA)-like organic species and a few OOA surrogates such as dicarboxylic, fulvic, and amino acids. The species chosen for the present study contain multi-functional oxygenated moieties and have high $\mathrm{O}: \mathrm{C}$ values that are more representative of ambient OOA species. We investigate the extent to which thermal decomposition of these species (cf. Reactions R1 and R2) bias elemental ratio measurements obtained with the AMS. AMS data from the laboratory standard molecules are used to re-evaluate the Aiken-Explicit and Aiken-Ambient methods for calculating elemental ratios. An "Improved-Ambient" (I-A) method (for AMS measurements performed in air) is determined as part of this study; the changes caused by application of the Improved-Ambient method to previously published ambient and chamber data are discussed. Empirical relationships used to determine $\mathrm{O}: \mathrm{C}$ and $\mathrm{H}: \mathrm{C}$ ratios from unit mass resolution AMS spectra are also updated to reflect the improved calibrations.

\section{Methods}

\subsection{Aerosol standards}

A list of the aerosol standards used in this study is given in Table 1. This list includes alcohols, diacids, polyacids, esters, and other species with multiple functionalities such as keto and hydroxy acids. All of the standards were purchased from Sigma-Aldrich (purity ranges $>96 \%$ ) except for three synthesized standards including a racemic mixture of $\delta$-isoprene epoxydiol (IEPOX) diastereomers known to be intermediates in isoprene oxidation chemistry, as well as known isoprene-derived SOA constituents cis- and trans3-methyl-3,4-dihydroxytetrahydrofurans (Lin et al., 2012; Zhang et al., 2012).

Aerosol particles were generated by dissolving small amounts of each standard in about $100 \mathrm{~mL}$ of distilled water, followed by atomization. The standards were atomized with argon carrier gas instead if nitrogen, since gaseous nitrogen in air produces a very large peak at $\mathrm{m} / z 28$ that make $\mathrm{CO}^{+}$aerosol signals very difficult to separate and quantify (even at high-resolution). Detection of $\mathrm{CO}^{+}$is of great interest since this ion is a likely thermal decomposition fragment of acids and potentially other species in OOA. The resulting polydisperse aerosol was then dried (with two silica gel diffusion dryers in series) in order to remove any remaining water from the atomization process and sampled directly into the AMS. The humidity of the flow after drying was spot checked for several experiments and was found to re- producibly be $<4 \%$. Any $\mathrm{H}_{2} \mathrm{O}$ that was not removed from the particles after exposure to these conditions is likely to have been further lost by evaporation when the particles encounter the 2 mbar sampling conditions of the AMS aerodynamic lens. Taken together it is likely that the aerosol $\mathrm{H}_{2} \mathrm{O}$ was negligible in these experiments and uncertainties due to the presence of aerosol $\mathrm{H}_{2} \mathrm{O}$ should have been small. The atomization setup was thoroughly cleaned between standards and blank water runs were carried out in between standards to ensure that cleaning between each set of standards was successful.

\subsection{AMS operation and data analysis}

The HR-ToF-AMS instrument and its data analysis procedures have been described in detail in previous publications (Canagaratna et al., 2007; DeCarlo et al., 2006). The HRToF-AMS can be usually operated in two ion optical modes (V or W) with differing spectral resolutions. For these experiments the AMS was operated in the more sensitive V-mode. The resolution of this mode (resolving power of $\sim 3000$ ) was high enough to resolve the key isobaric fragments observed from the standards studied here. The higher signal levels observed in the V-mode also allowed for the use of low-concentration samples in the atomizer, thereby minimizing cross-contamination between standards and avoiding signal saturation of the AMS detector or acquisition card. Highresolution ions up to the molecular weight of each standard were fitted in order to account for all of its ion fragments. The AMS data analysis software packages SQUIRREL (version $1.51 \mathrm{H}$ ) and PIKA (version $1.10 \mathrm{H}$ ) were used for the analysis of the high-resolution mass spectra. This software allows for ready calculation of elemental ratios from both A-A and A-E methods. The A-A calculation uses the default organic fragmentation wave proposed by Aiken et al. (2008) and the A-E method uses a copy of the default organic fragmentation wave in which the entries for $m / z 28,18,17$, and 16 are replaced to use measured ion intensities rather than estimated values. The I-A elemental ratios discussed below use A-A values and marker ion relative intensities calculated from normalized organic mass spectra output by the PIKA software.

Data collection occurred over several months and some standards were repeatedly measured at different points in time with the same instrument. Fig. S1a in the Supplement shows the standard deviations in $\mathrm{O}: \mathrm{C}$ and $\mathrm{H}: \mathrm{C}$ values (calculated using Aiken-Ambient method) obtained during these measurements. As can be seen, for most standards $\mathrm{O}: \mathrm{C}$ and $\mathrm{H}: \mathrm{C}$ values obtained on a given instrument are reproducible to $<5$ and $<3 \%$, respectively. Figure $\mathrm{S} 1 \mathrm{~b}$ and c compare $\mathrm{O}: \mathrm{C}$ and $\mathrm{H}: \mathrm{C}$ values obtained for different standards on three AMS instruments. The values compare well across instruments $(\mathrm{O}: \mathrm{C}$ within $4 \%, \mathrm{H}: \mathrm{C}$ within $7 \%)$.

For most of the experiments the AMS vaporizer was operated at a power corresponding to $600{ }^{\circ} \mathrm{C}$. The thermocou- 
Table 1. A list of standards analyzed in this study and their molecular $\mathrm{O}: \mathrm{C}$ and $\mathrm{H}: \mathrm{C}$ ratios. Standards are categorized according to their functionality into broad groups. All standards were studied with EI AMS, while standards also studied with VUV-AMS are noted in the last column.

\begin{tabular}{|c|c|c|c|c|c|}
\hline & Name & Formula & $\mathrm{O}: \mathrm{C}$ & $\mathrm{H}: \mathrm{C}$ & VUV-AMS \\
\hline \multirow[t]{21}{*}{ Multifunctional } & Cis-Pinonic Acid & $\mathrm{C}_{10} \mathrm{H}_{14} \mathrm{O}_{3}$ & 0.3 & 1.4 & $\mathrm{X}$ \\
\hline & 2-Oxooctanoic Acid & $\mathrm{C}_{8} \mathrm{H}_{14} \mathrm{O}_{3}$ & 0.37 & 1.75 & \\
\hline & Acetylsalicylic Acid & $\mathrm{C}_{9} \mathrm{H}_{8} \mathrm{O}_{4}$ & 0.44 & 0.89 & $X$ \\
\hline & Homovanillic Acid & $\mathrm{C}_{9} \mathrm{H}_{10} \mathrm{O}_{4}$ & 0.44 & 1.11 & $X$ \\
\hline & 4-Acetylbutyric Acid & $\mathrm{C}_{6} \mathrm{H}_{10} \mathrm{O}_{3}$ & 0.5 & 1.67 & \\
\hline & 5-Oxoazaleic Acid & $\mathrm{C}_{9} \mathrm{H}_{14} \mathrm{O}_{5}$ & 0.55 & 1.56 & $X$ \\
\hline & Levulinic Acid & $\mathrm{C}_{5} \mathrm{H}_{8} \mathrm{O}_{3}$ & 0.6 & 1.6 & \\
\hline & Gamma Ketopimelic Acid & $\mathrm{C}_{7} \mathrm{H}_{10} \mathrm{O}_{5}$ & 0.71 & 1.43 & $\mathrm{X}$ \\
\hline & 3-Hydroxybutyric Acid & $\mathrm{C}_{4} \mathrm{H}_{8} \mathrm{O}_{3}$ & 0.75 & 2 & \\
\hline & 2-Ketobutyric Acid & $\mathrm{C}_{4} \mathrm{H}_{6} \mathrm{O}_{3}$ & 0.75 & 1.5 & \\
\hline & 3-Hydroxy-3-Methylglutaric Acid & $\mathrm{C}_{6} \mathrm{H}_{10} \mathrm{O}_{5}$ & 0.83 & 1.67 & \\
\hline & 1,3-Acetonedicarboxylic Acid & $\mathrm{C}_{5} \mathrm{H}_{6} \mathrm{O}_{5}$ & 1 & 1.2 & \\
\hline & ?-Ketoglutaric Acid & $\mathrm{C}_{5} \mathrm{H}_{6} \mathrm{O}_{5}$ & 1 & 1.2 & $\mathrm{X}$ \\
\hline & Lactic Acid & $\mathrm{C}_{3} \mathrm{H}_{6} \mathrm{O}_{3}$ & 1 & 1.67 & \\
\hline & Pyruvic Acid & $\mathrm{C}_{3} \mathrm{H}_{4} \mathrm{O}_{3}$ & 1 & 1.33 & \\
\hline & Citric Acid & $\mathrm{C}_{6} \mathrm{H}_{8} \mathrm{O}_{7}$ & 1.16 & 1.33 & $\mathrm{X}$ \\
\hline & Diglycolic Acid & $\mathrm{C}_{4} \mathrm{H}_{6} \mathrm{O}_{5}$ & 1.25 & 1.5 & \\
\hline & Malic Acid & $\mathrm{C}_{4} \mathrm{H}_{6} \mathrm{O}_{5}$ & 1.25 & 1.5 & $\mathrm{X}$ \\
\hline & Oxaloacetic Acid & $\mathrm{C}_{4} \mathrm{H}_{4} \mathrm{O}_{5}$ & 1.25 & 1 & \\
\hline & Glycolic Acid & $\mathrm{C}_{2} \mathrm{H}_{4} \mathrm{O}_{3}$ & 1.5 & 2 & \\
\hline & Tartaric Acid & $\mathrm{C}_{4} \mathrm{H}_{6} \mathrm{O}_{6}$ & 1.5 & 1.5 & $\mathrm{X}$ \\
\hline \multirow[t]{7}{*}{ Alcohols } & Cis-3-methyl-3,4-dihydroxytetrahydrofuran & $\mathrm{C}_{5} \mathrm{H}_{10} \mathrm{O}_{3}$ & 0.6 & 2 & \\
\hline & Racemic mixture of $\delta$-Isoprene Epoxydiols & $\mathrm{C}_{5} \mathrm{H}_{10} \mathrm{O}_{3}$ & 0.6 & 2 & \\
\hline & Trans-3-methyl-3,4-dihydroxytetrahydrofuran & $\mathrm{C}_{5} \mathrm{H}_{10} \mathrm{O}_{3}$ & 0.6 & 2 & \\
\hline & Mannitol & $\mathrm{C}_{6} \mathrm{H}_{14} \mathrm{O}_{6}$ & 1 & 2.33 & \\
\hline & Mannose & $\mathrm{C}_{6} \mathrm{H}_{12} \mathrm{O}_{6}$ & 1 & 2 & $X$ \\
\hline & Sucrose & $\mathrm{C}_{11} \mathrm{H}_{23} \mathrm{O}_{11}$ & 1 & 2.09 & $X$ \\
\hline & Xylitol & $\mathrm{C}_{5} \mathrm{H}_{12} \mathrm{O}_{5}$ & 1 & 2.4 & $\mathrm{X}$ \\
\hline \multirow[t]{9}{*}{ Diacids } & Sebacic Acid & $\mathrm{C}_{10} \mathrm{H}_{18} \mathrm{O}_{4}$ & 0.4 & 1.8 & \\
\hline & Azelaic Acid & $\mathrm{C}_{9} \mathrm{H}_{16} \mathrm{O}_{4}$ & 0.44 & 1.78 & \\
\hline & Pimelic Acid & $\mathrm{C}_{7} \mathrm{H}_{12} \mathrm{O}_{4}$ & 0.57 & 1.71 & $\mathrm{X}$ \\
\hline & Adipic Acid & $\mathrm{C}_{6} \mathrm{H}_{10} \mathrm{O}_{4}$ & 0.66 & 1.67 & $\mathrm{X}$ \\
\hline & Glutaric Acid & $\mathrm{C}_{5} \mathrm{H}_{8} \mathrm{O}_{4}$ & 0.8 & 1.6 & $\mathrm{X}$ \\
\hline & Maleic Acid & $\mathrm{C}_{4} \mathrm{H}_{4} \mathrm{O}_{4}$ & 1 & 1 & $\mathrm{X}$ \\
\hline & Succinic Acid & $\mathrm{C}_{4} \mathrm{H}_{6} \mathrm{O}_{4}$ & 1 & 1.5 & $\mathrm{X}$ \\
\hline & Malonic Acid & $\mathrm{C}_{3} \mathrm{H}_{4} \mathrm{O}_{4}$ & 1.33 & 1.33 & $\mathrm{X}$ \\
\hline & Oxalic Acid & $\mathrm{C}_{2} \mathrm{H}_{2} \mathrm{O}_{4}$ & 2 & 1 & \\
\hline \multirow[t]{3}{*}{ Polyacids } & 1,3,5-Cyclohexanetricarboxylic Acid & $\mathrm{C}_{6} \mathrm{H}_{9} \mathrm{O}_{6}$ & 1 & 1.5 & $\mathrm{X}$ \\
\hline & Tricarballylic Acid & $\mathrm{C}_{6} \mathrm{H}_{8} \mathrm{O}_{6}$ & 1 & 1.33 & $\mathrm{X}$ \\
\hline & 1,2,4,5-Benzenetetracarboxylic Acid & $\mathrm{C}_{6} \mathrm{H}_{6} \mathrm{O}_{8}$ & 1.33 & 1 & $\mathrm{X}$ \\
\hline \multirow[t]{4}{*}{ Esters } & Dibutyl Oxalate & $\mathrm{C}_{8} \mathrm{H}_{18} \mathrm{O}_{4}$ & 0.5 & 2.25 & \\
\hline & Gamma Ketopimelic Acid Dilactone & $\mathrm{C}_{6} \mathrm{H}_{8} \mathrm{O}_{4}$ & 0.57 & 1.14 & $\mathrm{X}$ \\
\hline & Ethyl Pyruvate & $\mathrm{C}_{5} \mathrm{H}_{8} \mathrm{O}_{3}$ & 0.6 & 1.6 & \\
\hline & Dimethyl 1,3-Acetonedicarboxylate & $\mathrm{C}_{7} \mathrm{H}_{10} \mathrm{O}_{5}$ & 0.71 & 1.43 & \\
\hline
\end{tabular}

ple readout from the vaporizer is sensitive to its exact placement on the vaporizer and can sometimes differ from instrument to instrument or vary with instrument use. Thus, the measurements were standardized by varying the vaporizer power to minimize the width of a monodisperse $350 \mathrm{~nm}$
$\mathrm{NaNO}_{3}$ aerosol size distribution measured by the AMS. The time-of-flight traces of the $\mathrm{NO}^{+}$ion $\left(\mathrm{m} / z\right.$ 30) from $\mathrm{NaNO}_{3}$ were monitored as a function of vaporizer ion current. The optimum AMS vaporizer current is obtained by subtracting 0.1 amps from the vaporizer current at which the narrow- 
- Multifunctional,Esters,Polyacids,Alcohols,Diacids; + Aiken(2007,2008)
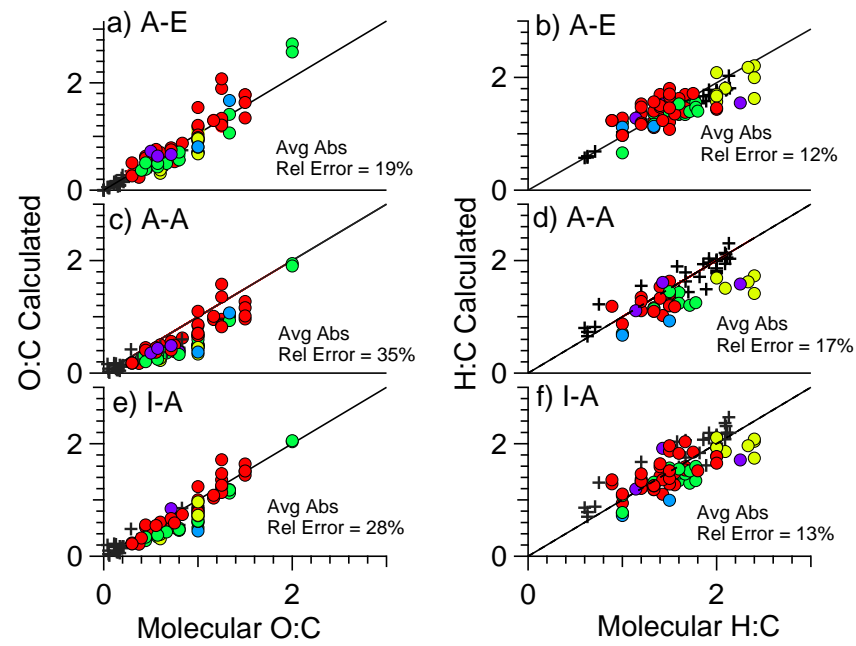

Figure 1. Scatterplots between known elemental compositions and AMS elemental ratios obtained with the Aiken-Explicit (A-E; panels $\mathbf{a}$ and b), Aiken-Ambient (A-A; panels $\mathbf{c}$ and d), and ImprovedAmbient methods (I-A; panels e and f). A 1:1 line is shown for reference in all plots. The standards examined in this study are colored according to their chemical functionality. Also shown are previously published standard molecule data from Aiken et al. (2007).

est $\mathrm{NO}^{+}$ion time-of-flight traces are observed from $\mathrm{NaNO}_{3}$. Typically this optimum AMS vaporizer current is near $1 \mathrm{amp}$. In most cases the thermocouple readout at the optimum heater power setting read temperatures in the range 590$600{ }^{\circ} \mathrm{C}$, indicating that the thermocouples in these instruments were providing a reasonably accurate measure of the actual heater temperature. In addition to the standard $600^{\circ} \mathrm{C}$ operation, a few experiments were also performed at $200^{\circ} \mathrm{C}$ (about the lowest temperature at which the AMS vaporizer can be operated continuously) in order to investigate how the amount of thermal decomposition and ion fragmentation changed with temperature. In both of these cases, the typical vaporization timescale for particles was measured to be on the order of $100 \mu \mathrm{s}$.

\subsection{VUV ionization}

Northway et al. (2007) described the adaptation of an HRToF-AMS to the vacuum ultraviolet (VUV) beam at the Advanced Light Source (Lawrence Berkeley Laboratory). We performed a similar adaptation in this study and generated and analyzed selected standards (see Table 1) using the same procedures discussed above. Previous work has shown that compared to $70 \mathrm{eV}$ EI-AMS spectra, VUV-AMS spectra are typically less complex, with reduced ion fragmentation and increased molecular ion intensity (Canagaratna et al., 2007; Northway et al., 2007). Molecular ions observed in VUVAMS spectra of unoxidized and slightly oxidized squalane have been successfully used to obtain chemical and mechanistic insight into the squalane oxidation reaction (Smith et al., 2009). Moreover, the tunability of the VUV light can be used to investigate the chemical identity of species by measuring their threshold ionization energy (Leone et al., 2010). The threshold ionization energy of most organic molecules is $10.5 \mathrm{eV}$ and those of $\mathrm{H}_{2} \mathrm{O}, \mathrm{CO}_{2}$, and $\mathrm{CO}$ molecules are $12.62,13.77$, and $14.01 \mathrm{eV}$, respectively (NIST Chemistry WebBook: http://webbook.nist.gov/chemistry/). Thus, in this experiment the 8 to $14.5 \mathrm{eV}$ VUV range was used.

\subsection{Elemental analysis (EA) methods}

The procedure for obtaining elemental ratios $(\mathrm{O}: \mathrm{C}, \mathrm{H}: \mathrm{C})$ from AMS spectra was first developed by Aiken et al. (2007, 2008). The atomic $\mathrm{O}: \mathrm{C}$ and $\mathrm{H}: \mathrm{C}$ ratios are obtained in terms of the relative mass concentrations of $\mathrm{O}\left(M_{\mathrm{O}}\right)$ and $\mathrm{C}\left(M_{\mathrm{C}}\right)$ and $\mathrm{H}\left(M_{\mathrm{H}}\right)$ as follows:

$\mathrm{O}: \mathrm{C}=\alpha_{\mathrm{O}: \mathrm{C}} \times\left(M_{\mathrm{O}} / M_{\mathrm{C}}\right) \times\left(\mathrm{MW}_{\mathrm{C}} / \mathrm{MW}_{\mathrm{O}}\right)$

$\mathrm{H}: \mathrm{C}=\alpha_{\mathrm{H}: \mathrm{C}} \times\left(M_{\mathrm{H}} / M_{\mathrm{C}}\right) \times\left(\mathrm{MW}_{\mathrm{C}} / \mathrm{MW}_{\mathrm{H}}\right)$

$\mathrm{MW}_{\mathrm{C}}, \mathrm{MW}_{\mathrm{O}}$, and $\mathrm{MW}_{\mathrm{H}}$ are the atomic weights of $\mathrm{C}, \mathrm{O}$, and $\mathrm{H}$, respectively. Since AMS ion intensities are proportional to the mass of the original molecules present (Jimenez et al., 2003), $M_{\mathrm{C}}, M_{\mathrm{O}}$, and $M_{\mathrm{H}}$ are obtained as a sum of the appropriate ion intensities across the complete organic spectrum (including $\mathrm{H}_{2} \mathrm{O}^{+}, \mathrm{CO}^{+}$, and $\mathrm{CO}_{2}^{+}$) as follows:

$M_{\mathrm{C}}=\sum_{j=m / z_{\min }}^{m / z_{\max }} I_{j} F_{\mathrm{c}}$

$M_{\mathrm{O}}=\sum_{j=m / z_{\min }}^{m / z_{\max }} I_{j} F_{\mathrm{O}}$

$M_{\mathrm{H}}=\sum_{j=m / z_{\min }}^{m / z_{\max }} I_{j} F_{\mathrm{H}}$

where $I_{j}$ is the ion intensity of the $j$ th ion in the spectrum and $F_{\mathrm{C}}, F_{\mathrm{O}}, F_{\mathrm{H}}$ are the relative carbon, oxygen, and hydrogen mass fractions for that ion. Calibration parameters $\left(\alpha_{\mathrm{O}}: \mathrm{C}\right.$ and $\left.\alpha_{\mathrm{H}: \mathrm{C}}\right)$ account for preferential losses of some atoms to neutral fragments rather than ion fragments during the fragmentation processes. The tendency of hydrocarbon fragments to form positive ions more readily than those containing the more electronegative $\mathrm{O}$ atom, for example, can result in such a detection bias. Aiken et al. (2008) obtained slopes of 0.75 and 0.91 (i.e., $\alpha_{\mathrm{O}: \mathrm{C}}=1 / 0.75$ and $\alpha_{\mathrm{H}: \mathrm{C}}=1 / 0.91$ ), respectively, by comparing measured and known $\mathrm{O}: \mathrm{C}$ and $\mathrm{H}: \mathrm{C}$ values for a range of organic standards according to Eqs. (1) and (2).

In AMS elemental analysis, Eqs. (1) and (2) are applied in two different ways which we refer to here as the AikenExplicit and Aiken-Ambient methods (Aiken et al., 2008). The Aiken-Explicit method is used when organic signals at 
$\mathrm{H}_{2} \mathrm{O}^{+}$and $\mathrm{CO}^{+}$can be directly measured. Laboratory measurements performed in an atmosphere of dry argon, for example, do not contain the interfering $\mathrm{H}_{2} \mathrm{O}$ or $\mathrm{N}_{2}$ species and allow for direct measurement of the organic signals at $\mathrm{CO}^{+}$ and $\mathrm{H}_{2} \mathrm{O}^{+}$. The organic signals at $\mathrm{CO}^{+}$have also been obtained under ambient conditions from AMS size distributions and by monitoring changes in the $m / z 28$ intensities (Zhang et al., 2005; Takegawa et al., 2007). Calibrations have also been carried out in laboratory chamber experiments under controlled relative humidity to determine the interference signals and obtain the organic signals at $\mathrm{CO}^{+}$and $\mathrm{H}_{2} \mathrm{O}^{+}$by subtraction (Chen et al., 2011; Nakao et al., 2013).

The Aiken-Ambient method is used for measurements performed in air where the interferences from gaseous $\mathrm{N}_{2}$ and $\mathrm{H}_{2} \mathrm{O}$ are difficult to estimate. Since most field measurements and laboratory chamber measurements are performed under the latter conditions, this method has in practice been the most widely used method of obtaining elemental ratios from AMS measurements. In the Aiken-Ambient method, the organic $\mathrm{H}_{2} \mathrm{O}^{+}$and $\mathrm{CO}^{+}$intensities used in Eqs. (3)(5) are empirically estimated rather than directly measured. The $\mathrm{H}_{2} \mathrm{O}^{+} / \mathrm{CO}_{2}^{+}$and $\mathrm{CO}^{+} / \mathrm{CO}_{2}^{+}$ratios recommended by Aiken et al. (2008) were empirically estimated from limited ambient $\mathrm{OA}$ measurements available at the time to be 0.225 and 1 , respectively. The $\mathrm{CO}^{+} / \mathrm{CO}_{2}^{+}$ratio was determined from AMS size distribution measurements where the gas-phase signal from $\mathrm{N}_{2}$ can be separated from the particle phase CO signal intensities (Zhang et al., 2005; Takegawa et al., 2007). The $\mathrm{H}_{2} \mathrm{O}^{+} / \mathrm{CO}_{2}^{+}$mass ratio was empirically estimated to conserve OA mass concentrations that resulted from the new $\mathrm{CO}^{+} / \mathrm{CO}_{2}^{+}$ratio. This $\mathrm{H}_{2} \mathrm{O}^{+} / \mathrm{CO}_{2}^{+}$empirical mass ratio corresponds to a raw ion signal ratio of either 0.225 , assuming $\mathrm{H}_{2} \mathrm{O}^{+}$and $\mathrm{CO}_{2}^{+}$were each formed with a relative ionization efficiency (RIE) of 1.4 or 0.321 , using a recently determined RIE of 2.0 for the formation of $\mathrm{H}_{2} \mathrm{O}^{+}$ (Mensah et al., 2011).

\section{Results and discussion}

\subsection{Evaluation of Aiken-Explicit and Aiken-Ambient methods}

We evaluated the performance of both Aiken-Explicit and Aiken-Ambient methods over a large range of species, including those with higher $\mathrm{O}: \mathrm{C}$ and more multifunctional moieties than originally studied by Aiken et al. (2008). Panels $a$ and $b$ in Fig. 1 show elemental ratios obtained with the Aiken-Explicit method for the laboratory standards studied here. The Aiken-Explicit method results reproduce actual $\mathrm{O}: \mathrm{C}$ and $\mathrm{H}: \mathrm{C}$ ratios for all the standard molecules with an average absolute value of the relative error (referred to as "error" in the rest of this manuscript) of 20 and $12 \%$, respectively. This is consistent with the accuracies reported by Aiken et al. (2008) and confirms that the Aiken-Explicit method can be used for a wide range of OA species.

Figures $1 \mathrm{c}$ and $1 \mathrm{~d}$ show Aiken-Ambient results for the laboratory standards. In general the Aiken-Ambient $\mathrm{O}: \mathrm{C}$ values are biased low for all the standards, and observed errors are dependent on the functional groups contained in the different standard molecules. The Aiken-Ambient values for multifunctional standard molecules are biased low by $28 \%$ and those for diacids and alcohols are biased low by $46 \%$. The error in Aiken-Ambient $\mathrm{H}: \mathrm{C}$ values for all standards is smaller, but alcohols and diacids are still biased low compared to multifunctional species.

\subsection{Measurements of $\mathrm{H}_{2} \mathrm{O}^{+}, \mathrm{CO}^{+}$and $\mathrm{CO}_{2}^{+}$signal intensities with Electron Ionization (EI)}

The only difference between the Aiken-Explicit and AikenAmbient methods is the measured vs. estimated $\mathrm{H}_{2} \mathrm{O}^{+}$and $\mathrm{CO}^{+}$ion intensities. Since these ion intensities are estimated based on assumed $\mathrm{H}_{2} \mathrm{O}^{+}$and $\mathrm{CO}^{+}$ratios to $\mathrm{CO}_{2}^{+}$, we investigate trends in the relative signal intensities of these three key ions in the observed standard mass spectra. Figure 2 shows the fractional AMS ion intensities (relative to the total ion signal for each standard) measured for these key thermal decomposition products in the spectra of the different laboratory standards. The standards are separated according to functionality, and they are arranged according to increasing molecular O : C. Measurements of the same standard on different instruments are shown as separate bars on the graph. The general agreement between different instruments supports the reproducibility and transferability of the results obtained here to other AMS instruments. The relative intensities of the three ions vary according to specific differences in the decomposition mechanisms including those shown in Reactions (R1) and (R2) above. Spectra from carboxylic acids, esters, polyacids, and multifunctional acids have higher $f_{\mathrm{CO}_{2}^{+}}$ (defined as the intensity of $\mathrm{CO}_{2}^{+}$divided by the total ion intensity) and $f_{\mathrm{CO}^{+}}$than alcohols, indicative of decarboxylation. On the other hand, spectra from alcohols have negligible $f_{\mathrm{CO}_{2}^{+}}$and significant $f_{\mathrm{H}_{2}} \mathrm{O}^{+}$, indicative of dehydration (Reaction R2).

Figure 3a shows the $f_{\mathrm{CO}^{+}}$vs. $f_{\mathrm{CO}_{2}^{+}}$scatterplot for all the standards in this study. For most multifunctional systems, the $f_{\mathrm{CO}^{+}} / f_{\mathrm{CO}_{2}^{+}}$ratio is relatively consistent with the assumed value of 1 from Aiken et al. (2008). The measured $f_{\mathrm{CO}^{+}} / f_{\mathrm{CO}_{2}^{+}}$ratios for alcohols and most diacids are $\geq 2$ which likely contributes to the additional underestimation in $\mathrm{O}: \mathrm{C}$ that is observed for these species with the AikenAmbient method. These measurements are generally consistent with previous studies that have shown that most laboratory SOA (thought to contain a mixture of multifunctional species) yield $f_{\mathrm{CO}^{+}} / f_{\mathrm{CO}_{2}^{+}}$values around 1 (Chhabra et al., 2010; Chen et al., 2011) with exceptions of SOA produced by isoprene photooxidation (2.63; Chen et al., 2011) and gly- 


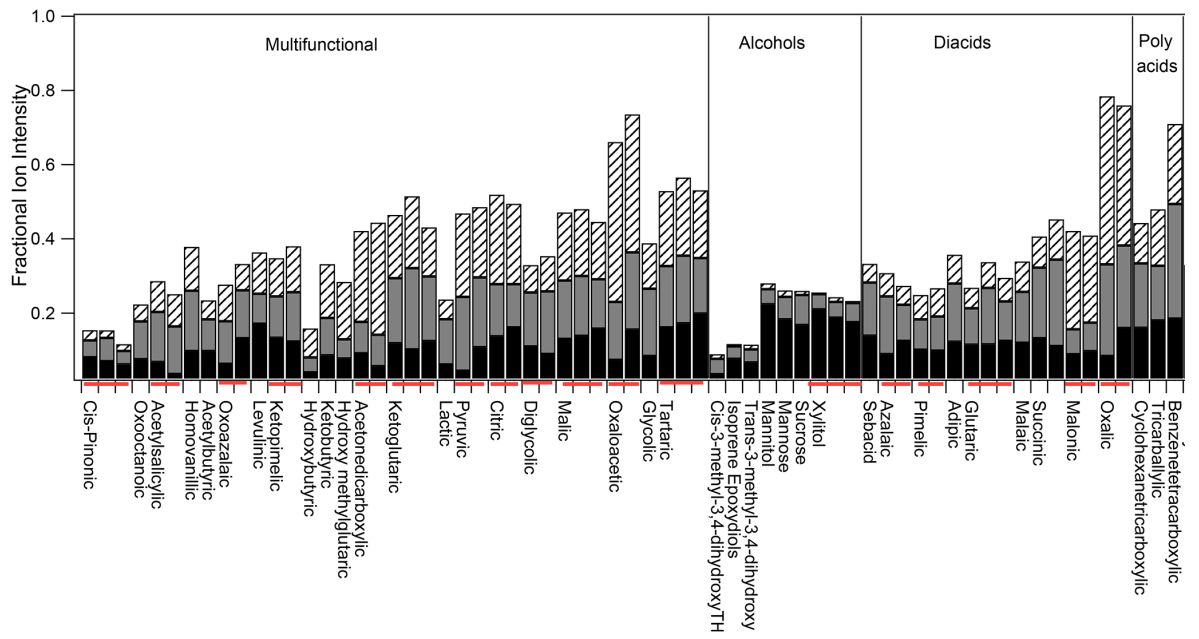

Figure 2. Fractional AMS ion intensities (relative to the total ion signal for each standard) measured for $\mathrm{CO}_{2}^{+}, \mathrm{CO}^{+}$, and $\mathrm{H}_{2} \mathrm{O}^{+}$from each of the laboratory aerosol standards studied here. The standards are classified according to functionality and then arranged according to increasing $\mathrm{O}: \mathrm{C}$. Repeat measurements were performed for some of the standards to investigate the consistency of measured mass spectra between different HR-ToF-AMS instruments. Repeat measurements performed for the same standard are arranged together and denoted by red horizontal bars on the bottom axis of the graph.

oxal uptake under dark, humid conditions (5.0; Chhabra et al., 2010), both of which contain products that are rich in hydroxyl functional groups but poor in carboxyl groups (Hastings et al., 2005; Lin et al., 2012). Ambient estimates are also in the similar range of 0.9-1.3 (Takegawa et al., 2007; Zhang et al., 2005). The $f_{\mathrm{CO}^{+}} / f_{\mathrm{CO}_{2}^{+}}$ratios discussed above are summarized in Table 2.

The relationships between $f_{\mathrm{H}_{2} \mathrm{O}^{+}}$and $f_{\mathrm{CO}_{2}^{+}}$for the standard spectra are shown in Fig. $3 \mathrm{~b}$ and Table 2. The observed signal intensity ratios in the spectra are larger than those calculated from the empirical mass ratios of Aiken et al. (2008). The measured $f_{\mathrm{H}_{2} \mathrm{O}^{+}} / f_{\mathrm{CO}_{2}^{+}}$ratio of multifunctional species varies from near 0 to over 2 , and many diacids are between 1 and 2 (although some are substantially lower than 1). Polyols and alcohol spectra have even higher ratios, mainly due to their lack of $\mathrm{CO}_{2}^{+}$. As shown in Table 2, similar departures from the assumed $f_{\mathrm{H}_{2} \mathrm{O}^{+}} / f_{\mathrm{CO}_{2}^{+}}$ratios were originally observed for chamber SO0A by Chen et al. (2011) (0.84-3.91) and more recently by Nakao et al. (2013) (0.33-1.23). We note that in mixed ambient aerosols the $f_{\mathrm{H}_{2} \mathrm{O}^{+}} / f_{\mathrm{CO}_{2}^{+}}$ratios would be moderated by the presence of species other than alcohols. However, high values for this ratio (1.0) were also reported for ambient measurements from Whistler Mountain (Sun et al., 2009). It is clear from Fig. 3 that the biases in the elemental ratios obtained with the Aiken-Ambient method are due to underestimations of the assumed $f_{\mathrm{H}_{2} \mathrm{O}^{+}} / f_{\mathrm{CO}_{2}^{+}}$and $f_{\mathrm{CO}^{+}} / f_{\mathrm{CO}_{2}^{+}}$values. The $\mathrm{H}_{2} \mathrm{O}^{+}$and $\mathrm{CO}^{+}$intensities observed for alcohols, in particular, are severely underestimated in the current assumptions since the estimates are tied to $\mathrm{CO}_{2}^{+}$, an ion that is not produced in any significant intensity in spectra

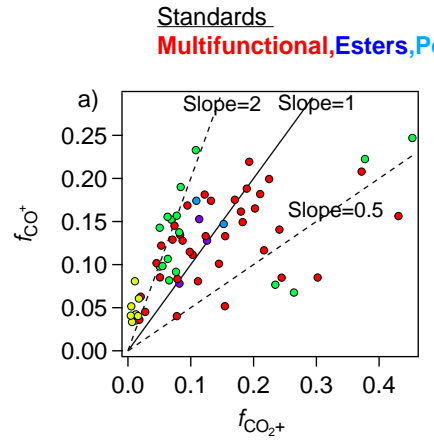

Standards

Multifunctional,Esters, Polyacids,Alcohols, Diacids

Figure 3. Scatterplots between AMS fractional ion intensities for $\mathrm{CO}^{+}$and $\mathrm{CO}_{2}^{+}$(panel a) and $\mathrm{H}_{2} \mathrm{O}^{+}$and $\mathrm{CO}_{2}^{+}$(panel b). The empirical ratios used for each of these relationships in the Aiken-Ambient calculations are shown as solid lines with the appropriate slopes. In panel (b), two solid lines are shown to reflect the measured ratios that correspond to possible $\mathrm{H}_{2} \mathrm{O}$ RIE values ranging from 1.4 to 2 (see Sect. 2 for more information). Dashed lines in both panels are included for reference to visualize the range of slope values.

of species that do not contain -C(O)OR moieties (e.g., alcohols).

In the Aiken-Ambient method, the intensities of the $\mathrm{OH}^{+}$ and $\mathrm{O}^{+}$fragments of $\mathrm{H}_{2} \mathrm{O}^{+}$are estimated according to the ratios measured for gas-phase $\mathrm{H}_{2} \mathrm{O}$. Figure $\mathrm{S} 4$ shows the scatterplots of measured $f_{\mathrm{OH}^{+}}$vs. $f_{\mathrm{H}_{2} \mathrm{O}^{+}}$and $f_{\mathrm{O}^{+}}$vs. $f_{\mathrm{H}_{2} \mathrm{O}^{+}}$ for all the laboratory standards. The empirical estimate used in the default AMS fragmentation table (Allan et al., 2004) for the $\mathrm{OH}^{+} / \mathrm{H}_{2} \mathrm{O}^{+}$ratio is very consistent with the observed relative intensities, indicating that the $\mathrm{OH}^{+}$ion indeed arises from the fragmentation of molecular water from 
Table 2. Summary of fragment ion ratios observed for standard molecules, chamber SOA, and ambient SOA. The entry * denotes the use of Aiken assumptions for the ratio in the fragment table.

\begin{tabular}{|c|c|c|c|c|c|}
\hline & $\begin{array}{l}\mathrm{Obs} \mathrm{H}_{2} \mathrm{O}^{+} / \\
\mathrm{CO}_{2}^{+}\end{array}$ & $\begin{array}{l}\mathrm{Obs} \mathrm{CO}^{+} / \\
\mathrm{CO}_{2}^{+}\end{array}$ & $\begin{array}{l}\text { Frag Wave } \mathrm{H}_{2} \mathrm{O}^{+} / \mathrm{CO}_{2}^{+} \\
\text {RIE } \mathrm{H}_{2} \mathrm{O}=1.4\end{array}$ & $\begin{array}{l}\text { Frag Wave } \mathrm{H}_{2} \mathrm{O}^{+} / \mathrm{CO}_{2}^{+} \\
\text {RIE } \mathrm{H}_{2} \mathrm{O}=2\end{array}$ & $\begin{array}{l}\text { Literature } \\
\text { Reference }\end{array}$ \\
\hline \multicolumn{6}{|l|}{ AMS Frag Table } \\
\hline Aiken Assumptions & 0.32 & 1 & 0.32 & 0.225 & Aiken et al. (2008) \\
\hline \multicolumn{6}{|l|}{ OA Standards } \\
\hline Multifunctional & $0.5-1.5$ & $1-2$ & $0.5-1.5$ & $0.35-1.05$ & This Study \\
\hline Polyacids & 1 & $1-2$ & 1 & 0.7 & \\
\hline Diacids & 2 & 2 & 2 & 1.4 & \\
\hline Esters & $0.5-1$ & 1 & $0.5-1$ & $0.35-0.7$ & \\
\hline Alcohols & $>10$ & $>4$ & $>10$ & $>7$ & \\
\hline \multicolumn{6}{|l|}{ Ambient Aerosol } \\
\hline Pittsburgh, USA & $*$ & 1.3 & $*$ & * & Zhang et al. (2005) \\
\hline Tokyo, Japan & $*$ & 1 & * & * & Takegawa et al. (2007) \\
\hline Whistler Mtn, Canada & 1 & $*$ & 1 & 0.7 & Sun et al. (2009) \\
\hline \multicolumn{6}{|l|}{ Chamber SOA } \\
\hline Isoprene Photooxidation (Low $\mathrm{NO}_{\mathrm{x}}$ ) & 3.9 & $1.03-2.6$ & 3.9 & 2.7 & $\begin{array}{l}\text { Chhabra et al. (2010), } \\
\text { Chen et al. (2011) }\end{array}$ \\
\hline Isoprene Photooxidation $\left(\mathrm{NO}_{\mathrm{x}}\right)$ & 0.3 & * & 0.3 & 0.2 & Nakao et al. (2013) \\
\hline$\alpha$-pinene $+\mathrm{O}_{3}$ & $0.8-1$ & $1-1.1$ & $0.8-1$ & $0.6-0.7$ & $\begin{array}{l}\text { Chhabra et al. (2010), } \\
\text { Chen et al. (2011), } \\
\text { Nakao et al. (2013) }\end{array}$ \\
\hline$\beta$-caryophyllene $+\mathrm{O}_{3}$ & $0.7-1.3$ & 1.2 & $0.7-1.3$ & $0.5-0.9$ & $\begin{array}{l}\text { Chen et al. (2011), } \\
\text { Nakao et al. (2013) }\end{array}$ \\
\hline Toluene Photooxidation $\left(\mathrm{NO}_{\mathrm{x}}\right)$ & 1.8 & 1 & 1.8 & 1.3 & Hildebrandt Ruiz et al. (2014) \\
\hline Aromatics Photooxidation $\left(\mathrm{NO}_{\mathrm{x}}\right.$, Low $\left.\mathrm{NO}_{\mathrm{x}}\right)$ & $0.3-1.3$ & $*$ & $0.3-1.3$ & $0.2-0.9$ & Nakao et al. (2013) \\
\hline Naphthalene Photooxidation $\left(\right.$ Low $\left.\mathrm{NO}_{\mathrm{x}}\right)$ & $*$ & 1.2 & * & $*$ & Chhabra et al. (2011) \\
\hline
\end{tabular}

thermal decomposition of the standards. The consistency in these fragmentation patterns also holds for various chamber SOA (Chen et al., 2011). The $\mathrm{O}^{+} / \mathrm{H}_{2} \mathrm{O}^{+}$ratio, in contrast, shows substantial scatter as the dominant source of the $\mathrm{O}^{+}$ for our standards appears to be fragmentation of $\mathrm{CO}_{2}^{+}$rather than $\mathrm{H}_{2} \mathrm{O}^{+}$(Fig. S4c). Alcohols, which do not produce $\mathrm{CO}_{2}^{+}$, are an exception with $\mathrm{O}^{+} / \mathrm{H}_{2} \mathrm{O}^{+}$ratios that are much closer to the empirical estimates. Fragmentation of $\mathrm{CO}_{2}^{+}$to yield $\mathrm{O}^{+}\left(\mathrm{O}^{+} / \mathrm{CO}_{2}^{+} \sim 6 \%\right)$ is currently not accounted for in the AMS elemental ratio analysis and will contribute to the underestimation observed in AMS O : C values.

\subsection{Measurements of $\mathrm{H}_{2} \mathrm{O}^{+}, \mathrm{CO}^{+}$and $\mathrm{CO}_{2}^{+}$with $\mathrm{VUV}$ ionization}

The $\mathrm{H}_{2} \mathrm{O}^{+}, \mathrm{CO}_{2}^{+}$, and $\mathrm{CO}^{+}$signals observed in the AMS are produced by dehydration and decarboxylation processes that take place before ionization (i.e., on the vaporizer surface or in the gas-phase after evaporation) and/or after $70 \mathrm{eV}$ electron-impact ionization (i.e., fragmentation of thermally excited ions). VUV-AMS measurements were used to examine the production mechanisms of these ions in more detail. VUV-AMS data were obtained for many standards with the AMS vaporizer set to both 200 and $600{ }^{\circ} \mathrm{C}$ (see Table 1). All experiments were carried out under an argon atmosphere. A VUV-AMS spectrum of glutaric acid is shown in Fig. 4a as an example. This spectrum was observed with the AMS va- porizer at $200^{\circ} \mathrm{C}$ and a VUV photon energy of $10.5 \mathrm{eV}$. Since VUV is a "softer" ionization method than EI, this spectrum would be expected to contain only the glutaric acid molecular ion if thermal decomposition on the vaporizer was negligible. However, even at this lower vaporizer temperature, the molecular ion of glutaric acid $(m / z 132)$ has very low intensity and organic ion fragments corresponding to loss of neutral $\mathrm{H}_{2} \mathrm{O}, \mathrm{CO}$, and $\mathrm{CO}_{2}$ from glutaric acid are observed instead. $\mathrm{CO}_{2}^{+}, \mathrm{CO}^{+}$, and $\mathrm{H}_{2} \mathrm{O}^{+}$are negligible in this spectrum at this VUV photon energy.

Figure $4 \mathrm{~b}$ shows the $\mathrm{CO}_{2}^{+}, \mathrm{CO}^{+}$, and $\mathrm{H}_{2} \mathrm{O}^{+}$signals observed from glutaric acid as a function of VUV energy. The onsets of $\mathrm{CO}_{2}^{+}, \mathrm{CO}^{+}$, and $\mathrm{H}_{2} \mathrm{O}^{+}$signals are observed to occur at VUV energies that correspond to the ionization energies of neutral $\mathrm{H}_{2} \mathrm{O}, \mathrm{CO}_{2}$, and $\mathrm{CO}$ molecules $(12.62,13.77$, and $14.01 \mathrm{eV}$, respectively), rather than the $10.5 \mathrm{eV}$ ionization energies of the observed organic ions. This indicates that these ions are formed by VUV ionization of neutral $\mathrm{CO}_{2}$, $\mathrm{CO}$, and $\mathrm{H}_{2} \mathrm{O}$ molecules rather than by dissociative ionization of glutaric acid. Neutral $\mathrm{CO}_{2}, \mathrm{CO}$, and $\mathrm{H}_{2} \mathrm{O}$ fragments formed upon photoionization of glutaric acid could further ionize to give rise to these signals. This process requires the absorption of two photons in the ionization region, however, and is therefore unlikely. Instead, the most likely source of $\mathrm{CO}_{2}^{+}, \mathrm{CO}^{+}$, and $\mathrm{H}_{2} \mathrm{O}^{+}$signals is direct VUV ionization of neutral $\mathrm{CO}_{2}, \mathrm{CO}$, and $\mathrm{H}_{2} \mathrm{O}$ molecules formed from thermal decomposition of organic species on the AMS vaporizer. 

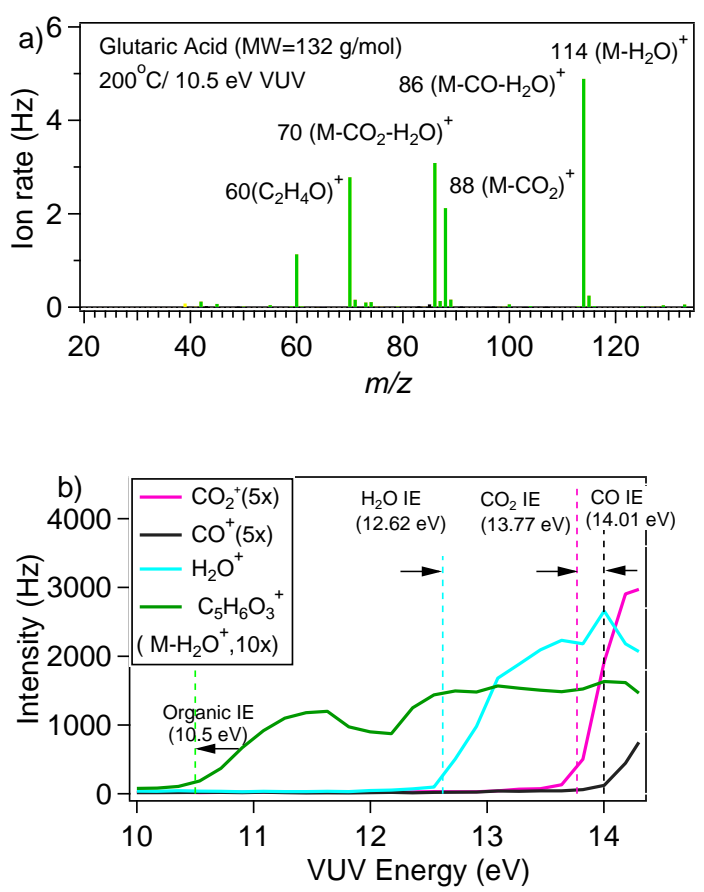

Figure 4. VUV-AMS spectrum of glutaric acid obtained under an argon atmosphere. The spectrum was obtained at a VUV energy of $10.5 \mathrm{eV}$ and a vaporizer temperature of $200^{\circ} \mathrm{C}$. Ions corresponding to loss of $\mathrm{CO}_{2}, \mathrm{CO}$, and $\mathrm{H}_{2} \mathrm{O}$ moieties from the parent ion $\left(\mathrm{M}^{+}\right)$are observed. (b) Glutaric acid VUV-AMS signals as a function of VUV monochromatic photon energy. The signal intensity of $\mathrm{C}_{5} \mathrm{H}_{6} \mathrm{O}_{3}^{+}$, which corresponds to the $\left[\mathrm{M}-\mathrm{H}_{2} \mathrm{O}\right]^{+}$ion, and the signal intensities of $\mathrm{CO}_{2}^{+}, \mathrm{CO}^{+}, \mathrm{H}_{2} \mathrm{O}^{+}$are shown. The gas phase ionization energies (IE) for neutral $\mathrm{CO}_{2}, \mathrm{CO}$, and $\mathrm{H}_{2} \mathrm{O}$ molecules are shown as colored vertical lines.

VUV-AMS measurements of the other organic standards also show a lack of parent ions and fragments corresponding to loss of $\mathrm{CO}_{2}, \mathrm{CO}$, or $\mathrm{H}_{2} \mathrm{O}$ moieties (see Fig. S2), indicating that a wide range of oxidized organic species undergo dehydration and decarboxylation upon heating to temperatures greater than $200^{\circ} \mathrm{C}$.

\subsection{Effect of vaporizer temperature on $\mathrm{H}_{2} \mathrm{O}^{+}, \mathrm{CO}^{+}$, and $\mathrm{CO}_{2}^{+}$}

Thermal denuder measurements have shown that ambient $\mathrm{OA}$ needs to be heated to a minimum temperature of $\sim 225^{\circ} \mathrm{C}$ for several seconds in order to insure quantitative vaporization of a significant fraction of ambient oxidized OA (Huffman et al., 2009). Figure S3 compares the trends in $f_{\mathrm{H}_{2} \mathrm{O}^{+}}, f_{\mathrm{CO}^{+}}$, and $f_{\mathrm{CO}_{2}^{+}}$observed with the AMS (using EI) at vaporizer temperatures of 600 and $200^{\circ} \mathrm{C}$. The total $\mathrm{CO}_{2}^{+}, \mathrm{CO}^{+}, \mathrm{H}_{2} \mathrm{O}^{+}$decomposition fragment intensities observed for both temperatures is remarkably similar across the standards. In most cases, $f_{\mathrm{H}_{2} \mathrm{O}^{+}}$is slightly higher at $200^{\circ} \mathrm{C}$ compared to $600^{\circ} \mathrm{C}$, while $f_{\mathrm{CO}^{+}}$follows the opposite trend and $f_{\mathrm{CO}_{2}^{+}}$changes little between the two temperatures. This indicates that dehydration is facile for these acids and alcohols even at $200^{\circ} \mathrm{C}$, which is also consistent with the VUV results shown in Fig. 4. The extent of thermal decomposition observed in the AMS is likely influenced by its specific vaporization conditions (i.e., porous tungsten hot surface and high-vacuum conditions). For example, Lloyd and Johnston (2009) reported that in laser-desorption-electronionization analysis of SOA, the signal due to $\mathrm{CO}_{2}^{+}$was much lower than in AMS spectra of the same aerosol type, and attributed the difference to differences in the vaporization conditions. Our measurements suggest that thermally induced decomposition could affect the interpretation of organic measurements from other aerosol chemistry measurement techniques that utilize thermal desorption on surfaces, even if temperatures of only $200{ }^{\circ} \mathrm{C}$ are reached. Such techniques include aerosol gas chromatography-mass spectrometry (GCMS) and thermal-desorption chemical ionization mass spectrometry (CIMS) (e.g., (Lopez-Hilfiker et al., 2014; Williams et al., 2006; Yatavelli and Thornton, 2010; Holzinger et al., 2013). Proton transfer reaction - mass spectrometry (PTRMS) measurements of heated ambient filters by Holzinger et al. (2010), for example, show low molecular weight fragments at higher thermal desorption temperatures, consistent with this finding. The specific impact of the surface materials, vaporization temperatures, and pressure conditions on the decomposition reactions of OA should be the focus of future studies.

\subsection{Improved-Ambient method}

It is clear from Fig. 3 that the relationships among $f_{\mathrm{CO}_{2}^{+}}, f_{\mathrm{H}_{2} \mathrm{O}^{+}}$, and $f_{\mathrm{CO}}^{+}$are variable and cannot be well prescribed with a single empirical relationship. Furthermore, as discussed in Sects. 3.2 and 3.3, O:C and $\mathrm{H}: \mathrm{C}$ calculated with the Aiken-Ambient method are biased low because the empirical estimates used in this method often underestimate the intensities of the $\mathrm{H}_{2} \mathrm{O}^{+}$and/or $\mathrm{CO}^{+}$fragments. Acidic species are observed to be a large source for $\mathrm{CO}^{+}$and $\mathrm{H}_{2} \mathrm{O}^{+}$ fragments while alcohols are a significant source of $\mathrm{H}_{2} \mathrm{O}^{+}$ fragments.

A correction that is dependent on both acid and alcohol content of the OA is needed to address this composition dependence in the OA fragmentation. Previous AMS measurements have shown that $f_{\mathrm{CO}_{2}}+$ can be used as a surrogate for acid content (Duplissy et al., 2011; Takegawa et al., 2007). An AMS surrogate for alcohol moieties has not been identified before, but spectra obtained during this study indicate that $f_{\mathrm{CHO}^{+}},(m / z 29)$ can be used as a surrogate for alcohol content. As shown in Fig. S5, spectra of standard species with no alcohol content have minimal $f_{\mathrm{CHO}^{+}}<0.05$, while those with non-zero alcohol content show $f_{\mathrm{CHO}^{+}}$values ranging from 0.05 to 0.15 . High $f_{\mathrm{CHO}^{+}}$values are found for polyols as well as multifunctional species with non-acid $\mathrm{OH}$ groups. Some esters are also observed to yield $f_{\mathrm{CHO}}$ similar to species with non-acid $\mathrm{OH}$ groups. The cleavage 
of aldehydes to give $\mathrm{CHO}^{+}$is not generally observed to be important (McLafferty and Turecek, 1993). Previous studies have shown that $\mathrm{CHO}^{+}$is also an atmospherically significant ion and a key oxygen-containing ion in many types of ambient and chamber aerosol (Ng et al., 2010a). The $f_{29}\left(f_{\mathrm{CHO}^{+}}\right)$ fragment has also been used to monitor photooxidation of glyoxal and related species in the aqueous phase (Lee et al., 2011). Based on these results, a composition-dependent correction factor with a linear dependence on $f_{\mathrm{CO}_{2}}$ and $f_{\mathrm{CHO}^{+}}$ was examined. While the $\mathrm{CHO}^{+}$fragment is easily resolved from the isobaric $\mathrm{C}_{2} \mathrm{H}_{5}^{+}$organic fragment in high-resolution AMS spectra, it overlaps with ${ }^{15} \mathrm{~N}^{14} \mathrm{~N}^{+}$fragments from $\mathrm{N}_{2}$ in air. Thus, a background correction must be used in order to obtain an accurate value of $f_{\mathrm{CHO}^{+}}$. AMS data acquired while sampling through a particle filter can be used to obtain the information needed for such a background correction (as is already necessary for the accurate determination of $f_{\mathrm{CO}_{2}}$ ).

We performed a multiple linear regression between the known elemental ratios of the OA standards and those determined from Eqs. (1) and (2) to obtain the best-fit constants and coefficients as follows:

$$
\begin{aligned}
& \mathrm{O}: \mathrm{C}_{\mathrm{I}-\mathrm{A}}= \\
& \mathrm{O}: \mathrm{C}_{\mathrm{A}-\mathrm{A}} \times\left[1.26-0.623 \times f_{\mathrm{CO}_{2}}++2.28 \times f_{\mathrm{CHO}^{+}}\right]
\end{aligned}
$$

$\mathrm{H}: \mathrm{C}_{\mathrm{I}-\mathrm{A}}=\mathrm{H}: \mathrm{C}_{\mathrm{A}-\mathrm{A}} \times\left[1.07+1.07 \times f_{\mathrm{CHO}^{+}}\right]$

In the equations above, the Improved-Ambient (I-A) elemental ratios are expressed as a product of Aiken-Ambient (AA) elemental ratios and a composition-dependent correction factor. This allows for simple recalculation of the ImprovedAmbient elemental ratios from Aiken-Ambient values without the need for performing a re-analysis of the raw mass spectra and can be easily applied to already published AMS results.

Figures 1e and 1f show the $\mathrm{O}: \mathrm{C}$ and $\mathrm{H}: \mathrm{C}$ values obtained for the standards after using the Improved-Ambient method in Eqs. (6) and (7). The corrections remove the systematic $\mathrm{O}: \mathrm{C}$ underestimation seen in Fig. 1c for the multi-functional species. The diacids and alcohols are still biased low in $\mathrm{O}: \mathrm{C}$, but the bias has been reduced. The errors in the $\mathrm{O}: \mathrm{C}$ and $\mathrm{H}$ : C elemental ratios calculated for the standards with the Improved-Ambient method are 28 and $13 \%$, respectively. Smaller errors (8\%) are observed for the values of OM : OC using the Improved-Ambient method (see Fig. S6).

Figure 5a compares the approximate carbon oxidation state values calculated from the Improved-Ambient elemental ratios and the known standard elemental ratios of the organic standards. The two sets of values agree within a standard deviation of $0.5 \overline{\mathrm{OS}}_{\mathrm{C}}$ units. The largest deviations are observed for the laboratory standards whose ImprovedAmbient $\mathrm{O}: \mathrm{C}$ values are biased lower than the known values. Figure $5 \mathrm{~b}$ shows a comparison between the $\overline{\mathrm{OS}}_{\mathrm{C}}$ values
- Default Frag Wave Multifunctional,Esters,Polyacids, Alcohols. Diacids - Hildebrandt Frag Wave

$+\quad$ Aiken et al. $(2007,2008)$
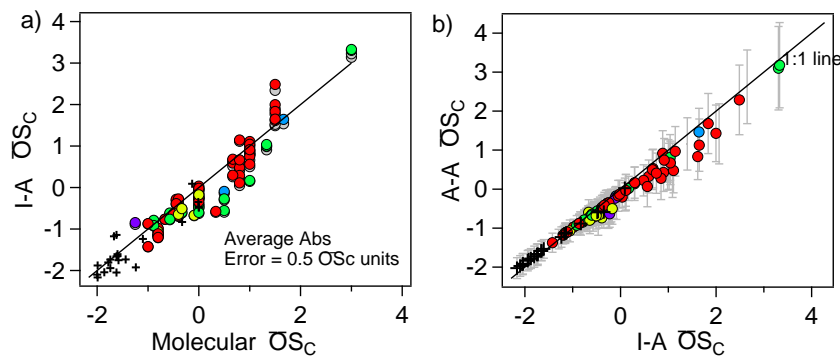

Figure 5. (a) Scatterplot of Improved-Ambient $\overline{\mathrm{OS}}_{\mathbf{C}}$ values $(2 \times \mathrm{O}: \mathrm{C}-\mathrm{H}: \mathrm{C})$ of the organic standards vs. their known molecular $\overline{\mathrm{OS}}_{\mathbf{C}}$ values. The Improved-Ambient method was applied with the default AMS organic fragmentation wave (colored solid circles) as well as with the Hildebrandt Ruiz et al. (2014) changes to the organic fragmentation wave. (b) Scatterplot of Aiken-Ambient $\overline{\mathrm{OS}}_{\mathrm{C}}$ values of the organic standards vs. the corresponding ImprovedAmbient method values. The error bars denote the propagated uncertainty in the Aiken-Ambient $\overline{\mathrm{OS}}_{\mathbf{C}}$ values due to the uncertainties in the Aiken-Ambient $\mathrm{O}: \mathrm{C}$ and $\mathrm{H}: \mathrm{C}$ values. The solid line shows the $1: 1$ relationship.

calculated for the standard molecule data using the AikenAmbient and Improved-Ambient methods. The error bars on the standard data indicate the estimated uncertainty in the calculated Aiken-Ambient $\overline{\mathrm{OS}}_{\mathbf{C}}$ values (using propagation of $\mathrm{O}: \mathrm{C}(\mathrm{H}: \mathrm{C})$ errors of $28 \%(14 \%)$ observed for multifunctional species with Aiken-Ambient method). In general, the agreement between the Aiken-Ambient $\overline{\mathrm{OS}}_{\mathbf{C}}$ values and the Improved-Ambient $\overline{\mathrm{OS}}_{\mathbf{C}}$ values is much better than the propagated errors. This indicates that the oxidation state values derived from AMS data (and potentially from other techniques using thermal desorption MS) are more robust and less variable than measured values of $\mathrm{H}: \mathrm{C}$ and $\mathrm{O}: \mathrm{C}$.

The robustness of the $\overline{\mathrm{OS}}_{\mathrm{C}}$ parameter is largely due to its invariance with respect to dehydration (and hydration) processes (Kroll et al., 2011). The $\overline{\mathrm{OS}}_{\mathbf{C}}$ value that is currently calculated from AMS spectra is not strictly invariant with respect to hydration and dehydration because the AMS fragmentation table neglects small amounts of $\mathrm{H}^{+}$formed from fragmentation of $\mathrm{H}_{2} \mathrm{O}^{+}$ions (Hildebrandt Ruiz et al., 2014). Other fragments, such as $\mathrm{OH}^{+}$, and $\mathrm{O}^{+}$are properly accounted for as discussed above. Figure 5a shows the effect of calculating Improved-Ambient $\overline{\mathrm{OS}}_{\mathrm{C}}$ values with a fragmentation table that includes the $\mathrm{H}^{+}$fragment (see Supplement for details). The Hildebrandt Ruiz et al. (2014) correction results in slightly smaller $\overline{\mathrm{OS}}_{\mathrm{C}}$ values than obtained with the default AMS fragmentation table due to a small $(<3 \%)$ increase in the Improved-Ambient $\mathrm{H}: \mathrm{C}$. 


\subsection{Estimated accuracy of the Improved-Ambient method for mixtures}

The errors observed in the Improved-Ambient elemental ratios of individual OA standards are expected to be upper limits for the corresponding errors in mixtures, where inaccuracies in individual molecule predictions can compensate for each other. The expected improvement in accuracy for mixtures is investigated here for randomly generated theoretical mixtures of the OA standard molecules.

Theoretical standard mixtures were generated by combining equimolar fractions of up to 25 different individual OA standards. Each mixture of individual standards is expressed as $\sum_{i} n_{i} \mathrm{C}_{x_{i}} \mathrm{H}_{y_{i}} \mathrm{O}_{z_{i}}$, where $n_{i}$ is the mole fraction of standard $i$ in the mixture, and $x_{i}, y_{i}$, and $z_{i}$ are the number of $\mathrm{C}, \mathrm{H}$, and $\mathrm{O}$ atoms within a molecule of standard $i$. The $\mathrm{O}: \mathrm{C}$ ratio for any given mixture is calculated as follows:

$\mathrm{O}: \mathrm{C}_{\operatorname{mix}(\mathrm{I}-\mathrm{A})}=\sum_{i}\left(\mathrm{O}: \mathrm{C}_{i(\mathrm{I}-\mathrm{A})} \times n_{i} x_{i}\right) / \sum_{i}\left(n_{i} x_{i}\right)$

$\mathrm{O}: \mathrm{C}_{\text {mix }(\text { Molecular })}=\sum_{i}\left(\mathrm{O}: \mathrm{C}_{\mathrm{i}(\text { molecular })} \times n_{i} x_{i}\right) / \sum_{i}\left(n_{i} x_{i}\right)$

$\mathrm{H}: \mathrm{C}$ ratios are calculated analogously with the appropriate substitutions in Eqs. (8) and (9). For each type of mixture, 1000 different randomly generated versions were examined and the average absolute value of relative errors in the calculated Improved-Ambient elemental ratios over all 1000 variants is calculated for each mixture. For the 1000 mixtures made of 25 standards, the $\mathrm{O}: \mathrm{C}$ ratios ranged from 0.3 to 0.83 and the $\mathrm{H}: \mathrm{C}$ ratios ranged from 1.36 to 1.92 . The mixtures made of 10 standards covered a wider range of $\mathrm{O}: \mathrm{C}$ ratios (0.18-1.02) and $\mathrm{H}: \mathrm{C}$ ratios (1.15-2.02). For comparison, the average Improved-Ambient $\mathrm{O}: \mathrm{C}(\mathrm{H}: \mathrm{C})$ values of $\mathrm{LV}-\mathrm{OOA}$ are $0.84(1.43)$ and of SV-OOA are 0.53 (1.62). Thus, the elemental ratios of the organic standard mixtures cover the range of ambient observations.

Figures $6 \mathrm{a}$ and $\mathrm{b}$ show the error in Improved-Ambient $\mathrm{O}: \mathrm{C}$ and $\mathrm{H}: \mathrm{C}$ values as a function of the number of standard molecules in the mixture of interest. It is clear from the figure that the error becomes smaller and plateaus for both of the elemental ratios as the number of OA species in the mixture is increased. For $\mathrm{O}: \mathrm{C}$ and $\mathrm{H}: \mathrm{C}$ the errors decrease from 28 to $12 \%$ and 13 to $4 \%$, respectively, as the number of species in the mixture is increased. The plateau in the error is already reached for both elemental ratios by the time that only 10 different standard OA species are added together. Ambient $\mathrm{OA}$ is a complex mixture of hundreds of individual species. If the standard molecule mixtures are reasonably representative of ambient OA mixtures, these results indicate that the Improved-Ambient $\mathrm{O}: \mathrm{C}$ and $\mathrm{H}: \mathrm{C}$ values calculated for ambient OA and SOA have errors close to $\sim 12$ and $\sim 4 \%$, respectively.
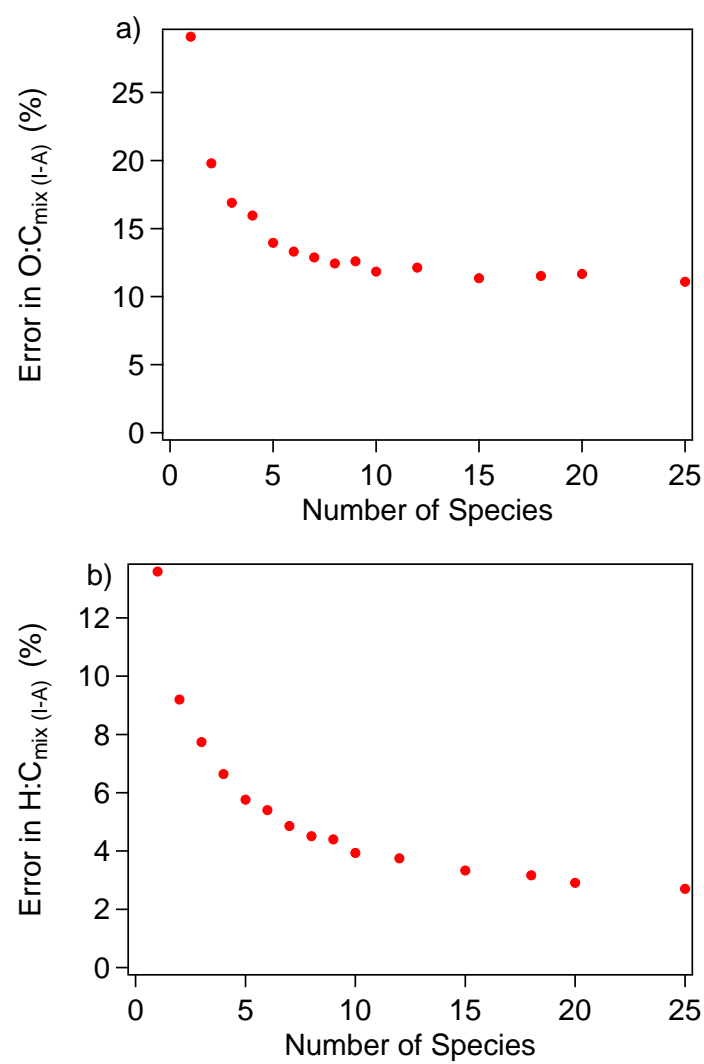

Figure 6. (a) Errors in Improved-Ambient $\mathrm{O}: \mathrm{C}$ ratio of organic standard molecule mixtures as a function of number of species in the mixture. (b) Errors in Improved-Ambient $\mathrm{H}$ : C ratio of the organic standard molecule mixtures as a function of number of species in the mixture.

\subsection{Effect of Improved-Ambient method on previous measurements of AMS elemental ratios}

Given the large number of AMS data sets that have reported OA elemental ratios calculated with the Aiken-Ambient technique, it is useful to examine the impact that the proposed corrections will have on existing results and their interpretation.

We focus on several HR-AMS data sets that have been analyzed with the Aiken-Ambient method and for which elemental ratios have been reported in the literature, and/or for which HR spectra are available on the HR-AMS spectral database (http://cires.colorado.edu/jimenez-group/ HRAMSsd/).

For ambient data sets, elemental ratios have been previously reported for total OA as well as OA components (i.e., groups of organic species that represent different OA sources and or processes). Primary OA (POA) species are directly emitted into the atmosphere while secondary OA (SOA) are species formed as a result of atmospheric transformation (Ulbrich et al., 2009; Zhang et al., 2011; Lanz et al., 2007). Several types of POA have been identified, includ- 


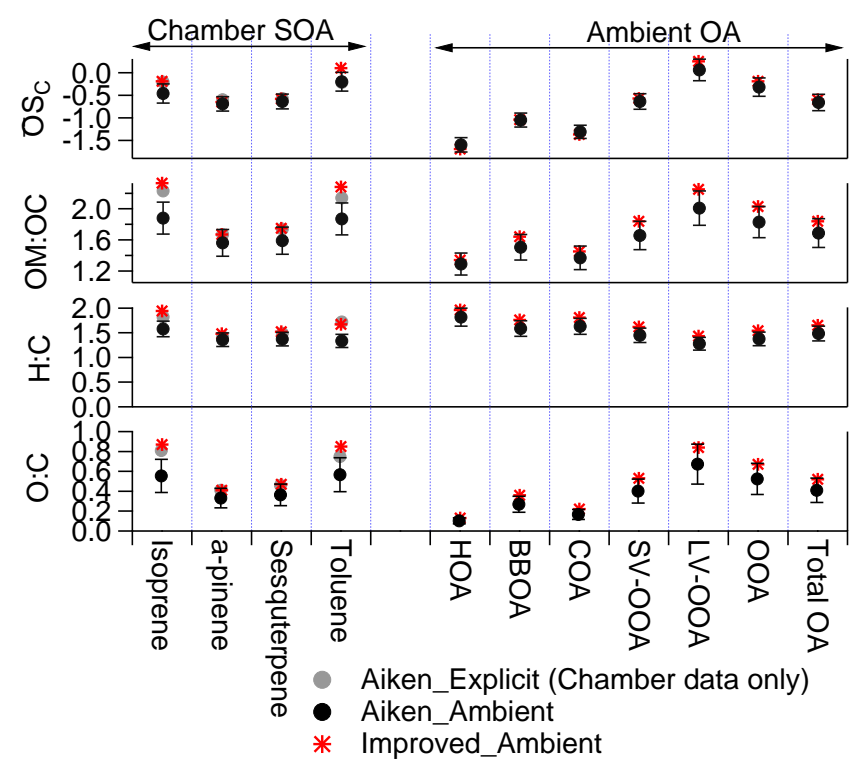

Figure 7. Summary of elemental composition information obtained across chamber and ambient OA measurements. The figure shows values obtained with the Improved-Ambient method as well as the Aiken-Ambient method. Aiken-Ambient elemental ratios are shown with errors from Aiken et al. $(2007,2008)$ for reference. For the chamber data, Aiken-Explicit values measured by Chen et al. (2011) and Hildebrandt Ruiz et al. (2014) are also shown. The elemental composition information shown for ambient OA is averaged over the data sets shown in Table S1 and S2 in the Supplement.

ing hydrocarbon-like organic aerosol (HOA), which is associated with fossil fuel combustion and other urban sources, biomass burning OA (BBOA), cooking OA (COA), and other OA from local sources (LOA) (Zhang, et al., 2011 and references therein). SOA species, which generally dominate ambient OA mass concentrations, consist of a continuum of oxidized organic aerosol species (OOA), which reflects differences in extent and mechanisms of photochemical aging as well as precursor sources ( $\mathrm{Ng}$ et al., 2010b; Jimenez et al., 2009). Two broad types of ambient SOA, denoted as LVOOA (low volatility oxidized organic aerosol) and SV-OOA (semi-volatile oxidized organic aerosol), have been identified at many locations. LV-OOA represent the more highly oxidized organic aerosol while SV-OOA are the less oxidized OA.

Figure 7 shows the average $\mathrm{O}: \mathrm{C}, \mathrm{H}: \mathrm{C}, \mathrm{OM}: \mathrm{OC}$, and $\overline{\mathrm{OS}}_{\mathbf{C}}$ values obtained when previously published field and chamber SOA data are analyzed using the ImprovedAmbient method. Aiken-Ambient values are shown for all data and Aiken-Explicit values are shown for the chamber SOA. The data for Fig. 7 are available in Table 3 and the detailed values for each field data set are in Tables S1 and S2 in the Supplement. The Improved-Ambient elemental ratios of chamber SOA are higher than previously reported Aiken-Ambient values and the relative change varies with the identity of the precursor. For the $\alpha$-pinene $+\mathrm{O}_{3}$ and $\beta$-caryophyllene $+\mathrm{O}_{3} \mathrm{SOA}$ (Chen et al., 2011), the predicted increase in $\mathrm{O}: \mathrm{C}(\mathrm{H}: \mathrm{C})$ is smaller than that for the isoprene $+\mathrm{OH}$ (Chen et al., 2011) and toluene + OH SOA (Hildebrandt Ruiz et al., 2014). These differences are likely linked to the specific molecular functionalities associated with SOA formed from each precursor. Isoprene SOA, for example, is known to produce organic peroxides (Surratt et al., 2006) and polyols (Claeys et al., 2004) while major products of toluene SOA are known to be small acids (Fisseha et al., 2004). The largest increases are comparable to those observed for the standard molecules with diacid and polyol functionalities while the smaller increases are consistent with those observed for multifunctional standards. The ImprovedAmbient elemental ratios of ambient OA (individual components as well as total OA) generally lie at the high error limit of the Aiken-Ambient values. The Improved-Ambient $\mathrm{O}: \mathrm{C}$ and $\mathrm{H}: \mathrm{C}$ values of total $\mathrm{OA}$, for example are larger than the corresponding Aiken-Ambient values by approximately 27 and $11 \%$ on average. These relative differences are similar to those observed for the multifunctional OA standards (Fig. 1c) and smaller than those observed for some of the individual chamber SOA systems or individual SOA standards.

Figure 7 shows that chamber SOA elemental ratios calculated with the Improved-Ambient method agree well with those calculated using the Aiken-Explicit method. This agreement is important since it confirms that the ImprovedAmbient method compares well with the Aiken-Explicit method not only for laboratory standards but also for OA mixtures with complex compositions and molecular functionalities that cannot be readily duplicated with commercial standards. Recently, agreement between gas and particle phase elemental ratio measurements of highly oxidized, extremely low-volatility organic compounds (ELVOCs) formed in the $\alpha$-pinene $+\mathrm{O}_{3}$ reaction has also been demonstrated (Ehn et al., 2014). This agreement was found when lowvolatility oxidized products (ELVOCs) were measured as individual molecules in the gas phase using CIMS and as condensed particle phase species using AMS and the ImprovedAmbient method. The proposed auto-oxidation mechanism in Ehn et al. (2014) indicates that the ELVOCs probably have multiple hydroperoxide moieties. Though hydroperoxides are not represented in the calibration set, the agreement between the individually identified ELVOCs measured in Ehn et al. (2014) and the O:C of low-concentration $\alpha$ pinene SOA obtained from AMS data using the Improved method describe here is encouraging.

While the Improved-Ambient only corrects the elemental ratio values obtained with the AMS, the resulting increase in both $\mathrm{O}: \mathrm{C}$ and $\mathrm{H}: \mathrm{C}$ values implies an increase in organic mass as well. On average, the OM:OC ratios obtained with the Improved-Ambient method for total OA are $9 \%$ higher than previously published Aiken-Ambient values. The average Improved-Ambient OM : OC ratio of total OA is 1.84 with variation from $1.3-1.5$ for primary OA com- 
ponents to $1.8-2.2$ for secondary OA components; chamber SOA Improved-Ambient OM : OC ratios vary with precursor. The OM : OC ratio of the ambient OOA components is consistent with water soluble fraction of aged ambient aerosol, which has been measured by other techniques to be in the range of 2.1 (Turpin and Lim, 2001) to 2.54 (Polidori et al., 2008). A fit of the Improved-Ambient OM : OC data results in the following empirical relationship (see Fig. S5):

$\mathrm{OM}: \mathrm{OC}_{\mathrm{I}-\mathrm{A}}=1.29 \times \mathrm{O}: \mathrm{C}_{\mathrm{I}-\mathrm{A}}+1.17$

In Fig. 7, it is important to note that the carbon oxidation state of total OA calculated with the Improved-Ambient method remains relatively unchanged from that determined by the Aiken-Ambient method (Improved-Ambient $\overline{\mathrm{OS}}_{\mathrm{C}}$ is higher by only 0.06 ). The $\overline{\mathrm{OS}}_{\mathrm{C}}$ values from the two methods also agree closely even for the chamber systems that display larger differences in $\mathrm{O}: \mathrm{C}$ and $\mathrm{H}: \mathrm{C}$ values (see Fig. 7). This reinforces the conclusion that $\overline{\mathrm{OS}}_{\mathrm{C}}$ is a more robust measure of OA oxidation levels than either $\mathrm{O}: \mathrm{C}$ or $\mathrm{H}: \mathrm{C}$ since is not affected by hydration or dehydration processes taking place in the atmosphere or during the measurement process and is thus also not sensitive to other sources of $\mathrm{H}_{2} \mathrm{O}$ in aerosol samples such as aerosol water or dehydration of inorganic acids (Kroll et al., 2011).

The corrected elemental analysis values will have implications for the interpretation of van Krevelen diagrams (i.e., plots of $\mathrm{H}: \mathrm{C}$ vs. $\mathrm{O}: \mathrm{C}$ ), which have been used to obtain insights into the chemical transformations of ambient OA. Heald et al. (2010) first showed the utility of this diagram for bulk total OA (including POA and SOA) composition analysis, and demonstrated that for some data sets bulk ambient OA evolved with a slope of -1 , suggesting composition changes with aging that are consistent with simultaneous increases in both carbonyl and alcohol moieties. $\mathrm{Ng}$ et al. (2011) used the van Krevelen diagram to follow the oxidative transformations of ambient OOA (as opposed to total OA) from multiple field campaigns and showed that they clustered along a slope of approximately -0.5 . This slope was interpreted as being indicative of simple oxidative mechanisms that involve net additions of both $\mathrm{C}(\mathrm{O}) \mathrm{OH}$ and $-\mathrm{OH} /-$ $\mathrm{OOH}$ functional groups without fragmentation (i.e., $\mathrm{C}-\mathrm{C}$ bond cleavage), and/or the addition of $\mathrm{C}(\mathrm{O}) \mathrm{OH}$ groups with fragmentation. Van Krevelen plots of ambient and chamber SOA species from Table 3 are shown in Fig. S7. The Improved-Ambient method yields van Krevelen slopes that are approximately $20 \%$ shallower than those determined with the Ambient-Aiken method. Details are discussed in Chen et al., 2014. These slopes ( -0.8 for total OA and -0.4 for OOA) suggest that the ambient OA oxidative mechanisms involve different net addition of $-\mathrm{OH}$ and/or $-\mathrm{OOH}$ functionalities and fragmentation than previously assumed.

\subsection{Effect of improved-ambient method on empirical parameterizations of $\mathrm{OA}$ elemental ratios from unit mass resolution data}

Empirical methods relating unit mass resolution (UMR) AMS ion tracers with Ambient-Aiken elemental ratios obtained from high-resolution AMS data have been previously reported by Aiken et al. (2008) and Ng et al. (2011). Here we reassess these relationships for elemental ratios calculated with the Improved-Ambient method.

Aiken et al. (2008) presented a parameterization to estimate $\mathrm{O}: \mathrm{C}$ from measured $f_{44}$ values. High-resolution AMS measurements indicate that the UMR signal at $m / z 44$ is mostly due to $\mathrm{CO}_{2}^{+}$, although $\mathrm{C}_{2} \mathrm{H}_{4} \mathrm{O}^{+}$can play a role in some cases (e.g., isoprene SOA and BBOA). Figure 8a shows Improved-Ambient $\mathrm{O}: \mathrm{C}$ values for standard, chamber, and ambient field data vs. $f_{44}$. A linear fit of the field OA components (primary and secondary) provides the following parameterization for Improved-Ambient $\mathrm{O}: \mathrm{C}$ values:

$\mathrm{O}: \mathrm{C}_{\mathrm{I}-\mathrm{A}}=0.079+4.31 \times f_{44}$

Equation (11) reproduces most of the data points including all the ambient OA components obtained by factor analysis. The O : Cs calculated with Eq. (11) reproduce measured secondary OA component values with an error of $13 \%$. The agreement for primary OA components is not as good, indicating that the accuracy of Eq. (11) is reduced when $f_{44}$ is small ( $<4 \%$ on average). The outliers in Fig. 6a correspond to species with low acid content and high alcohol content (i.e., polyols, and other multifunctional species with $\mathrm{OH}$ groups). Thus, the inferred $\mathrm{O}: \mathrm{C}$ values for some types of marine aerosols that have been shown to contain alcohol functionalities (Hawkins and Russell, 2010) may be somewhat underpredicted. The chamber data outliers in Fig. 8a also indicate that Eq. (11) may underpredict $\mathrm{O}: \mathrm{C}$ values substantially in ambient environments dominated by $\mathrm{NO}_{\mathrm{x}}$-free isoprene chemistry and toluene chemistry.

$\mathrm{Ng}$ et al. (2011) derived a method for estimating $\mathrm{H}: \mathrm{C}$ values of OOA components and SOA species from $f_{43}$. This parameterization was based on ambient OOA components and chamber SOA species with $f_{44}>0.05$ and $f_{43}>0.04$. For these species, $m / z 43$ is typically dominated by $\mathrm{C}_{2} \mathrm{H}_{3} \mathrm{O}^{+}$. Only a few of the measured multifunctional standards yield mass spectra which fall within these prescribed valid ranges. Since these few data points do not add enough significant information to derive a new parameterization, we use them together with chamber and field data to evaluate a scaled version of the $\mathrm{Ng}$ et al. (2011) relationship. We choose a scaling factor of 1.11 since the Improved-Ambient method increases the $\mathrm{H}$ : $\mathrm{Cs}$ of ambient $\mathrm{OA}$ by $11 \%$ on average. The resulting scaled parameterization is as follows:

SOA H : $\mathrm{C}_{\mathrm{I}-\mathrm{A}}=1.12+6.74 \times f_{43}-17.77 \times f_{43}^{2}$

Figure $8 \mathrm{~b}$ compares the parameterization from Eq. (12) with the measured Improved-Ambient $\mathrm{H}: \mathrm{C}$ values. The figure in- 
Table 3. Summary of elemental composition information obtained for chamber and ambient OA.

\begin{tabular}{|c|c|c|c|c|c|c|c|c|c|}
\hline & \multicolumn{4}{|c|}{ Improved-Ambient } & \multicolumn{4}{|c|}{ Change (with respect to Aiken-Ambient) } & \multirow[t]{2}{*}{ Literature Reference } \\
\hline & $\mathrm{O}: \mathrm{C}$ & $\mathrm{H}: \mathrm{C}$ & $\mathrm{OM}: \mathrm{OC}$ & OSc & $\mathrm{O}: \mathrm{C}(\%)$ & $\mathrm{H}: \mathrm{C}(\%)$ & $\mathrm{OM}: \mathrm{OC}(\%)$ & OSc (Absolute) & \\
\hline Ambient OA & & & & & & & & & $\begin{array}{l}\text { Aiken et al. (2009), Chen et al. (2009), } \\
\text { Chen et al.,(2014), Decarlo et al. (2010), } \\
\text { Docherty et al. (2011), Ge et al., (2012), } \\
\text { Gong et al. (2012), He et al. (2011), } \\
\text { Wang et al. (2010), Huang et al.(2011), } \\
\text { Huang et al.(2012), Huang et al.(2013), } \\
\text { Martin et al.(2008), Mohr et al. (2012), } \\
\text { Ovadnevaite, et al. (2011), Poulain et al.(2011), } \\
\text { Robinson et al. (2011), Saarikoski et al. (2012), } \\
\text { Setyan et al. (2012), Sun et al. (2011) }\end{array}$ \\
\hline Total OA & 0.52 & 1.65 & 1.84 & -0.60 & 27 & 11 & 9 & 0.06 & \\
\hline \multicolumn{5}{|c|}{ Primary Components } & & & & & \\
\hline $\mathrm{HOA}$ & 0.13 & 1.96 & 1.34 & -1.69 & 27 & 8 & 4 & -0.09 & \\
\hline BBOA & 0.36 & 1.76 & 1.64 & -1.04 & 34 & 11 & 9 & 0.01 & \\
\hline $\mathrm{COA}$ & 0.22 & 1.81 & 1.45 & -1.37 & 32 & 11 & 6 & -0.06 & \\
\hline \multicolumn{5}{|c|}{ Secondary Components } & & & & & \\
\hline SV-OOA & 0.53 & 1.62 & 1.84 & -0.57 & 32 & 12 & 11 & 0.07 & \\
\hline LV-OOA & 0.84 & 1.43 & 2.25 & 0.25 & 25 & 12 & 12 & 0.19 & \\
\hline Total OOA & 0.67 & 1.54 & 2.03 & -0.19 & 28 & 12 & 11 & 0.13 & \\
\hline \multicolumn{5}{|l|}{ Chamber SOA } & & & & & \\
\hline Isoprene & 0.87 & 1.94 & 2.33 & -0.19 & 57 & 23 & 24 & 0.27 & Chen et al. (2011) \\
\hline$\alpha$-pinene & 0.41 & 1.48 & 1.67 & $-0,65$ & 24 & 9 & 7 & 0.04 & Chen et al. (2011) \\
\hline$\beta$-caryophyllene & 0.47 & 1.52 & 1.75 & -0.58 & 29 & 11 & 10 & 0.06 & Chen et al. (2011) \\
\hline Toluene & 0.85 & 1.67 & 2.28 & 0.10 & 50 & 25 & 22 & 0.30 & Hildebrandt Ruiz et al. (2014) \\
\hline
\end{tabular}

Standards

Multifunctional, Esters

Polyacids, Alcohols, Diacids

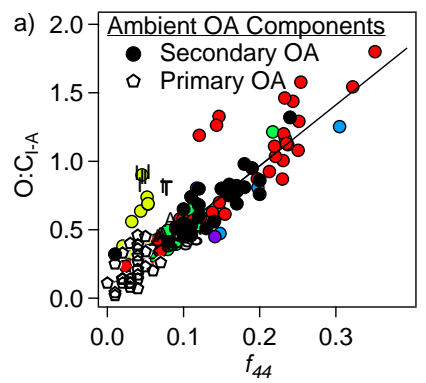

Chamber SOA A a-pinene S Sesquiterpene I Isoprene $\mathrm{T}$ Tolune

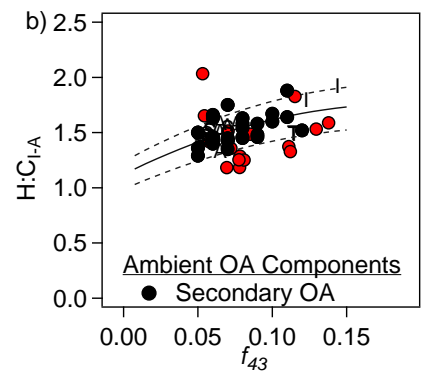

Figure 8. Scatterplot between Improved-Ambient $\mathrm{O}: \mathrm{C}$ values and $f_{44}$ (fractional ion intensity at $\mathrm{m} / \mathrm{z} 44$ from unit mass resolution data). Ambient OA component data from field campaigns are shown as black points. The black line shows the linear fit through the ambient $\mathrm{OA}\left(\mathrm{O}: \mathrm{C}_{\mathrm{I}-\mathrm{A}}=0.079+4.31 \times f_{44}\right)$. Chamber SOA and standard OA data are also shown in the figure. (b) Scatterplot between Improved-Ambient $\mathrm{H}: \mathrm{C}$ values and $f_{43}$ for ambient secondary OA components and chamber SOA. OA standard data is shown for the few multifunctional species which fit the criteria for this parameterization $\left(f_{44}>0.05\right.$ and $\left.f_{43}>0.04\right)$. The solid line shows a scaled version of the $\mathrm{Ng}$ et al. parameterization $\left(\mathrm{H}: \mathrm{C}_{\text {Improved Ambient }}=\right.$ $\left.1.12+6.74 \times f_{43}-17.77 \times f_{43}^{2}\right)$ and the dotted lines show $\pm 10 \%$ deviations from the parameterization. dicates that as in $\mathrm{Ng}$ et al. (2011), the measured $\mathrm{H}$ : $\mathrm{C}$ values for secondary OA components, secondary chamber OA, and several standard molecules are reproduced to within $\pm 10 \%$ by Eq. (12).

\subsection{Atmospheric implications}

Aerosol elemental ratios measured with the AMS have been previously used to distinguish between different types of organic aerosol (Jimenez et al., 2009; Ng et al., 2010), examine the degree to which chamber SOA is able to simulate ambient SOA (Chhabra et al., 2010; $\mathrm{Ng}$ et al., 2010), and to constrain oxidation mechanisms used in theoretical models (Jimenez et al., 2009; Kroll et al., 2011; Donahue et al., 2011; Daumit et al., 2013; Chen et al., 2014). Here we show that while the changes introduced by the Improved-Ambient method can be significant, they do not change any fundamental conclusions made from previous AMS studies.

As shown in Fig. 7, I-A elemental ratios for ambient OA components have the same trends with respect to each other as previously published A-A elemental ratios. The relative levels of oxidation for the various OA components, for example, do not change with respect to each other. The OOA components still span a continuum of oxidation levels; LVOOA components remain more oxidized than SV-OOA components, and OOA components remain more oxidized than the various POA components (Jimenez et al., 2009). In fact, the Improved-Ambient method enhances previous conclu- 
sions about the high degree of oxygenation of atmospheric OOA, indicating that ambient OA has a greater oxygen content than suggested by previous AMS studies.

Laboratory chamber studies provide the ideal means of simulating ambient aerosol formation and aging processes under controlled and reproducible experimental conditions (i.e., selected reactants, photochemical conditions, and aging times). However, previous work has shown that laboratory chamber studies are unable to generate SOA or photochemically aged OA with the same chemical composition as the LV-OOA species observed in the atmosphere (Chhabra et al., 2010; Ng et al., 2010). The elemental ratios obtained with I-A method reconfirm this difference. Figure 7 shows, for example, that the I-A elemental ratios observed for the SOA from terpene and sesquiterpene precursors are significantly less oxidized than the average ambient LV-OOA component. In fact, the terpene and sesquiterpene chamber SOA generally only reach the O:C and OSc values observed for the less oxidized SV-OOA components. As shown in Table 2, the I-A elemental ratios of isoprene and toluene SOA experience large changes compared to their corresponding A-A values. These changes are large enough to bring the $\mathrm{O}: \mathrm{C}$ and OSc values of these SOA in good agreement with LVOOA values. However, as shown in Fig. 4a, the oxygen containing functional groups in these SOA still do not reproduce the mass spectral signatures obtained from ambient LV-OOA. Thus, the gap in the AMS chemical compositions measured for chamber and ambient SOA remains even when the I-A method is used.

Many studies have used elemental ratios $(\mathrm{O}: \mathrm{C}$ and $\mathrm{H}: \mathrm{C})$ or the oxidation state values derived from them as key constraints to understand how OA chemical composition evolves in the atmosphere. Some two-dimensional chemical spaces that directly use these parameters as constraints are the van Krevelen space discussed in Sect. 3.7 of this manuscript, OSc vs. carbon number, and OSc vs. saturation vapor concentration (Jimenez et al., 2009; Kroll et al., 2011; Donahue et al., 2011). Daumit et al. (2013) have used a three-dimensional space (carbon number, $\mathrm{O}: \mathrm{C}, \mathrm{H}: \mathrm{C}$ ) to constrain and define the chemically feasible back-reactions that could lead to the oxidized LV-OOA species observed in the atmosphere. In all of these spaces the measured bulk values of $\mathrm{O}: \mathrm{C}, \mathrm{H}: \mathrm{C}$, and OSc provide mechanistic insight by limiting the reaction pathways and intermediates that are potentially possible. Daumit et al. (2013) have compared the difference in constraints introduced when LV-OOA elemental ratios are calculated using A-A and I-A methods (The I-A elemental ratios in Daumit et al. (2013) were calculated by scaling A$\mathrm{A} \mathrm{O}: \mathrm{C}$ and $\mathrm{H}: \mathrm{C}$ ratios by 1.3 and 1.11 , respectively). For the same LV-OOA volatility, elemental ratios obtained with the I-A method constrain the LV-OOA composition to contain a higher hydroxyl/ carbonyl ratio than the elemental ratios obtained with the A-A method. Since hydroxyl groups result in lower volatility than carbonyl groups, this implies that the average LV-OOA carbon number calculated using the
I-A constraints is lower than that calculated using A-A constraints. From the standpoint of chemical mechanisms, this also means that the new I-A constraints will result in the need for new reactions that produce more hydroxyl groups relative to carbonyl groups. This is consistent with the general trend noticed in the van Krevelen diagrams (see Sect. 3.7) which indicate that ambient $\mathrm{OA}$ oxidation increases $\mathrm{O}: \mathrm{C}$ while maintaining high $\mathrm{H}: \mathrm{C}$ values. This suggests that models should explore different and or additional mechanisms for adding - $\mathrm{OH}$ and/or - $\mathrm{OOH}$ functionalities during oxidation of ambient OA.

\section{Conclusions}

This manuscript evaluates the accuracy of the AMS elemental analysis approach over a wider range of OA species than has been studied before. Thermally induced dehydration and/or decarboxylation of OA species is observed to be efficient in the AMS not only at the standard vaporizer temperature of $600^{\circ} \mathrm{C}$ but also at much lower vaporizer temperatures (even $200^{\circ} \mathrm{C}$, the lowest feasible vaporization temperature). These processes likely also play a role in other heated surface vaporization-based aerosol measurement techniques even if they limit heating to $\sim 200^{\circ} \mathrm{C}$. The $\mathrm{H}_{2} \mathrm{O}, \mathrm{CO}$, and $\mathrm{CO}_{2}$ molecules produced by these decomposition processes must be taken into account in order to obtain accurate elemental composition information.

The accuracy of elemental ratios obtained with the AMS depends on the exact method that is used. The Aiken-Explicit method reproduces known $\mathrm{O}: \mathrm{C}$ and $\mathrm{H}: \mathrm{C}$ ratios to within 20 and $12 \%$, respectively. These results validate the use of this methodology for calculating elemental ratios across a range of OA molecular compositions. This method is recommended for laboratory experiments and smog-chamber measurements as well as ambient measurements when a sufficient signal is available (e.g., at very polluted sites). Careful control of the sampling conditions and/or calibration experiments that enable unambiguous extraction of the organic signal contributions to measured $\mathrm{H}_{2} \mathrm{O}^{+}$and $\mathrm{CO}^{+}$ion intensities are recommended for these situations (see for example Chen et al., 2011). The Aiken-Ambient method (used for most measurements of aerosols obtained in air) produces $\mathrm{O}: \mathrm{C}(\mathrm{H}: \mathrm{C})$ ratios for multifunctional species that are within $28 \%$ (14\%) of known ratios, respectively. These values are biased low, however, with larger biases observed for some highly functionalized species (e.g., polyols and polycarboxylic acids). Detailed analysis of the AMS spectra indicate that these biases are largely due to the use of empirically estimated intensities for $\mathrm{H}_{2} \mathrm{O}^{+}$and $\mathrm{CO}^{+}$ions that that are lower than the actual measured values for these ions. An Improved-Ambient method for calculating elemental ratios from OA is developed as part of this study and is recommended for measurements obtained in air. This method combines the Aiken-Ambient results together with correction 
factors that uses specific ion fragments as markers to reduce composition-dependent bias and produce $\mathrm{O}: \mathrm{C}(\mathrm{H}: \mathrm{C})$ values for the standard molecules that are within $28 \%(13 \%)$ of the known molecular values. Future work should include comparisons between the OA elemental ratios obtained with the Improved-Ambient technique and other elemental analysis techniques.

Application of the Improved-Ambient elemental analysis to previously published ambient data sets results in an average increase of the $\mathrm{O}: \mathrm{C}$ and $\mathrm{H}: \mathrm{C}$ values of total $\mathrm{OA}$ by 27 and $11 \%$, respectively; the $\mathrm{OM}: \mathrm{OC}$ ratios of total organic correspondingly increases by $9 \%$. The oxidation state values calculated with the Aiken-Ambient and Improved-Ambient methods, on the other hand, do not differ substantially since $\overline{\mathrm{OS}}_{\mathrm{C}}$ is invariant with respect to hydration and dehydration processes. This indicates that $\overline{\mathrm{OS}}_{\mathrm{C}}$ is a more robust parameter for monitoring oxidation of aerosols than either $\mathrm{O}: \mathrm{C}$ or $\mathrm{H}: \mathrm{C}$; comparisons between $\overline{\mathrm{OS}}_{\mathrm{C}}$ measurements from the AMS and other elemental analysis techniques are needed to investigate this in more detail.

The Improved-Ambient method indicates that the oxygen content of ambient OA is larger than reported by previous AMS measurements. The chemistry involved in the formation of highly oxidized ambient OOA is still poorly characterized, and chemical pathways that produce high values of $\mathrm{O}: \mathrm{C}$ are unclear. Thus, more work is required to develop and explore alternative chemical mechanisms and modeling methods for simulating the formation of highly oxidized ambient OA. The van Krevelen slope resulting from the Improved-Ambient formulation is also shallower than previously reported ( -0.8 for total OA and -0.4 for OOA). Aging mechanisms of ambient $\mathrm{OA}$ that qualitatively involve greater net addition of $-\mathrm{COH}$ and $-\mathrm{COOH}$ groups relative to $-\mathrm{CO}$ groups should be explored.

\section{The Supplement related to this article is available online at doi:10.5194/acp-15-253-2015-supplement.}

Acknowledgements. We thank the participants of AMS Clinic and AMS Users Meetings, Paul Ziemann, and Colette Heald for many useful discussions on these topics. J. H.Kroll, M. R.Canagaratna, and D. R.Worsnop acknowledge support from NSF CHE-1012809. J. L.Jimenez was partially supported by NSF AGS-1243354, NASA NNX12AC03G and NOAA NA13OAR4310063. Q.Chen is supported by the National Science Foundation (ATM-1238109). N. M.Donahue is supported by the National Science foundation (AGS1136479). K. R.Wilson and the Chemical Dynamics Beamline (Advanced Light Source) are supported by the Office of Basic Energy Sciences of the US Department of Energy under contract no. DE-AC02-05CH11231. K. R.Wilson is additionally supported by the Department of Energy, Office of Science Early Career Research Program. E. Fortner, L. R. Williams, and J. T. Jayne acknowledge support from the US Department of Energy (DEFG02-03ER83599, DE-FG02-05ER84269, DE-FG02-07ER84890)

Edited by: N. L. Ng

\section{References}

Aiken, A. C., DeCarlo, P. F., and Jimenez, J. L.: Elemental Analysis of Organic Species with Electron Ionization HighResolution Mass Spectrometry, Anal. Chem., 79, 8350-8358, doi:10.1021/ac071150w, 2007.

Aiken, A. C., DeCarlo, P. F., Kroll, J. H., Worsnop, D. R., Huffman, J. A., Docherty, K., Ulbrich, I. M., Mohr, C., Kimmel, J. R., Sueper, D., Sun, Y., Zhang, Q., Trimborn, A., Northway, M., Ziemann, P. J., Canagaratna, M. R., Onasch, T. B., Alfarra, M. R., Prevot, A. S. H., Dommen, J., Duplissy, J., Metzger, A., Baltensperger, U., and Jiménez, J. L.: O/C and OM/OC Ratios of Primary, Secondary, and Ambient Organic Aerosols with a High Resolution Time-of-Flight Aerosol Mass Spectrometer, Environ. Sci. Technol., 42, 4478-4485, 2008.

Allan, J. D., Coe, H., Bower, K. N., Alfarra, M. R., Delia, A. E., Jiménez, J. L., Middlebrook, A. M., Drewnick, F., Onasch, T. B., Canagaratna, M. R., Jayne, J. T., and Worsnop, D. R.: Technical note: Extraction of chemically resolved mass spectra from Aerodyne aerosol mass spectrometer data, J. Aerosol Sci., 35, 909-922, 2004.

Altieri, K. E., Turpin, B. J., and Seitzinger, S. P.: Composition of Dissolved Organic Nitrogen in Continental Precipitation Investigated by Ultra-High Resolution FT-ICR Mass Spectrometry, Environ. Sci. Technol., 43, 6950-6955, 2009.

Bateman, A. P., Nizkorodov, S. A., Laskin, J., and Laskin, A.: Timeresolved molecular characterization of limonene/ozone aerosol using high-resolution electrospray ionization mass spectrometry, Phys. Chem. Chem. Phys., 11, 7931-7942, 2009.

Canagaratna, M. R., Jayne, J. T., Jiménez, J. L., Allan, J. D., Alfarra, M. R., Zhang, Q., Onasch, T. B., Drewnick, F., Coe, H., Middlebrook, A., Delia, A., Williams, L. R., Trimborn, A. M., Northway, M. J., DeCarlo, P. F., Kolb, C. E., Davidovits, P., and Worsnop, D. R.: Chemical and Microphysical Characterization of Ambient Aerosols with the Aerodyne Aerosol Mass Spectrometer, Mass Spectrom. Rev., 26, 185-222, 2007.

Chen, Q., Farmer, D. K., Schneider, J., Zorn, S. R., Heald, C. L., Karl, T. G., Guenther, A., Allan, J. D., Robinson, N., Coe, H., Kimmel, J. R., Pauliquevis, T., Borrmann, S., Poschl, U., Andreae, M. O., Artaxo, P., Jimenez, J. L., and Martin, S. T.: Mass spectral characterization of submicron biogenic organic particles in the Amazon Basin, Geophys. Res. Lett., 36, L20806, doi:10.1029/2009g1039880, 2009.

Chen, Q., Liu, Y. D., Donahue, N. M., Shilling, J. E., and Martin, S. T.: Particle-Phase Chemistry of Secondary Organic Material: Modeled Compared to Measured O : C and H : C Elemental Ratios Provide Constraints., Environ. Sci. Technol., 45, 4763-4770, 2011.

Chen, Q., Heald, C. L., Jimenez, J. L., Canagaratna, M. R., Zhang, Q., He, L., Huang, X., Campuzano-Jost, P., Palm, B. B., Poulain, L., Martin, S. T., Abbatt, J. P. D., Lee, A. K. Y., and Liggio, J.: Elemental Composition of Organic Aerosol: The Gap Between 
Ambient and Laboratory Measurements, Geophys. Res. Lett., submitted, 2014.

Chhabra, P. S., Flagan, R. C., and Seinfeld, J. H.: Elemental analysis of chamber organic aerosol using an aerodyne high-resolution aerosol mass spectrometer, Atmos. Chem. Phys., 10, 4111-4131, doi:10.5194/acp-10-4111-2010, 2010.

Claeys, M., Graham, B., Vas, G., Wang, W., Vermeylen, R., Pashynska, V., Cafmeyer, J., Guyon, P., Andreae, M. O., Artaxo, P., and Maenhaut, W.: Formation of secondary organic aerosols through photooxidation of isoprene, Science, 11731176, doi:10.1126/science.1092805, 2004.

Daumit, K. E., Kessler, S. H., and Kroll, J. H.: Average chemical properties and potential formation pathways of highly oxidized organic aerosol, Faraday Discussions, 165, 181-202, 2013.

DeCarlo, P. F., Kimmel, J. R., Trimborn, A., Northway, M. J., Jayne, J. T., Aiken, A. C., Gonin, M., Fuhrer, K., Horvath, T., Docherty, K., Worsnop, D. R., and Jiménez, J. L.: A FieldDeployable High-Resolution Time-of-Flight Aerosol Mass Spectrometer, Anal. Chem., 78, 8281-8289, 2006.

DeCarlo, P. F., Ulbrich, I. M., Crounse, J., de Foy, B., Dunlea, E. J., Aiken, A. C., Knapp, D., Weinheimer, A. J., Campos, T., Wennberg, P. O., and Jimenez, J. L.: Investigation of the sources and processing of organic aerosol over the Central Mexican Plateau from aircraft measurements during MILAGRO, Atmos. Chem. Phys., 10, 5257-5280, doi:10.5194/acp-10-52572010, 2010.

Docherty, K. S., Aiken, A. C., Huffman, J. A., Ulbrich, I. M., DeCarlo, P. F., Sueper, D., Worsnop, D. R., Snyder, D. C., Peltier, R. E., Weber, R. J., Grover, B. D., Eatough, D. J., Williams, B. J., Goldstein, A. H., Ziemann, P. J., and Jimenez, J. L.: The 2005 Study of Organic Aerosols at Riverside (SOAR-1): instrumental intercomparisons and fine particle composition, Atmos. Chem. Phys., 11, 12387-12420, doi:10.5194/acp-11-12387-2011, 2011.

Donahue, N. M., Epstein, S. A., Pandis, S. N., and Robinson, A. L.: A two-dimensional volatility basis set: 1. organic-aerosol mixing thermodynamics, Atmos. Chem. Phys., 11, 3303-3318, doi:10.5194/acp-11-3303-2011, 2011.

Duplissy, J., DeCarlo, P. F., Dommen, J., Alfarra, M. R., Metzger, A., Barmpadimos, I., Prevot, A. S. H., Weingartner, E., Tritscher, T., Gysel, M., Aiken, A. C., Jimenez, J. L., Canagaratna, M. R., Worsnop, D. R., Collins, D. R., Tomlinson, J., and Baltensperger, U.: Relating hygroscopicity and composition of organic aerosol particulate matter, Atmos. Chem. Phys., 11, 11551165, doi:10.5194/acp-11-1155-2011, 2011.

Ehn, M., Thornton, J. A., Kleist, E., Sipila, M., Junninen, H., Pullinen, I., Springer, M., Rubach, F., Tillmann, R., Lee, B., LopezHilfiker, F., Andres, S., Acir, I.-H., Rissanen, M., Jokinen, T., Schobesberger, S., Kangasluoma, J., Kontkanen, J., Nieminen, T., Kurten, T., Nielsen, L. B., Jorgensen, S., Kjaergaard, H. G., Canagaratna, M., Maso, M. D., Berndt, T., Petaja, T., Wahner, A., Kerminen, V.-M., Kulmala, M., Worsnop, D. R., Wildt, J., and Mentel, T. F.: A large source of low-volatility secondary organic aerosol, Nature, 506, 476-479, 2014.

Fisseha, R., Dommen, J., Sax, M., Paulsen, D., Kalberer, M., Maurer, R., Hoefler, F., Weingartner, E., and Baltensperger, U.: Identification of Organic Acids in Secondary Organic Aerosol and the Corresponding Gas Phase from Chamber Experiments, Anal. Chem., 76, 6535-6540, 2004.
Fuzzi, S., Decesari, S., Facchini, M. C., Matta, E., and Mircea, M.: A simplified model of the water soluble organic component of atmospheric aerosols, Geophys. Res. Lett., 28, 4079-4082, 2001.

Ge, X. L., Setyan, A., Sun, Y. L., and Zhang, Q.: Primary and secondary organic aerosols in Fresno, California during wintertime: Results from high resolution aerosol mass spectrometry, J. Geophys. Res., 117, D19301, doi:10.1029/2012jd018026, 2012.

Gilardoni, S., Liu, S., Takahama, S., Russell, L. M., Allan, J. D., Steinbrecher, R., Jimenez, J. L., De Carlo, P. F., Dunlea, E. J., and Baumgardner, D.: Characterization of organic ambient aerosol during MIRAGE 2006 on three platforms, Atmos. Chem. Phys., 9, 5417-5432, doi:10.5194/acp-9-5417-2009, 2009.

Gong, Z., Lan, Z., Xue, L., Zeng, L., He, L., and Huang, X.: Characterization of submicron aerosols in the urban outflow of the central Pearl River Delta region of China, Frontiers of Environmental Science \& Engineering, 6, 725-733, doi:10.1007/s11783012-0441-8, 2012.

Hastings, W. P., Koehler, C. A., Bailey, E. L., and De Haan, D. O.: Secondary organic aerosol formation by glyoxal hydration and oligomer formation: Humidity effects and equilibrium shifts during analysis, Environ. Sci. Technol., 39, 8728-8735, 2005.

Hawkins, L. N. and Russell, L. M.: Polysaccharides, proteins, and phytoplankton fragments: four chemically distinct types of marine primary organic aerosol classified by single particle spectromicroscopy, Advances in Meteorology, 2010, 612132, doi:10.1155/2010/612132, 2010.

He, L. Y., Huang, X. F., Xue, L., Hu, M., Lin, Y., Zheng, J., Zhang, R. Y., and Zhang, Y. H.: Submicron aerosol analysis and organic source apportionment in an urban atmosphere in Pearl River Delta of China using high-resolution aerosol mass spectrometry, J. Geophys. Res., 116, D12304, doi:10.1029/2010jd014566, 2011.

Heald, C. L., Kroll, J. H., Jimenez, J. L., Docherty, K. S., DeCarlo, P. F., Aiken, A. C., Chen, Q., Martin, S. T., Farmer, D. K., and Artaxo, P.: A simplified description of the evolution of organic aerosol composition in the atmosphere, Geophys. Res. Lett., 37, L08803, doi:08810.01029/02010GL042737, 2010.

Hildebrandt Ruiz, L., Paciga, A. L., Cerully, K., Nenes, A., Donahue, N. M., and Pandis, S. N.: Aging of secondary organic aerosol from small aromatic VOCs: changes in chemical composition, mass yield, volatility and hygroscopicity, Atmos. Chem. Phys. Discuss., 14, 31441-31481, doi:10.5194/acpd-14-314412014, 2014.

Holzinger, R., Kasper-Giebl, A., Staudinger, M., Schauer, G., and Röckmann, T.: Analysis of the chemical composition of organic aerosol at the Mt. Sonnblick observatory using a novel high mass resolution thermal-desorption proton-transfer-reaction mass-spectrometer (hr-TD-PTR-MS), Atmos. Chem. Phys., 10, 10111-10128, doi:10.5194/acp-10-10111-2010, 2010.

Holzinger, R., Goldstein, A. H., Hayes, P. L., Jimenez, J. L., and Timkovsky, J.: Chemical evolution of organic aerosol in Los Angeles during the CalNex 2010 study, Atmos. Chem. Phys., 13, 10125-10141, doi:10.5194/acp-13-10125-2013, 2013.

Huang, X.-F., He, L.-Y., Hu, M., Canagaratna, M. R., Kroll, J. H., Ng, N. L., Zhang, Y.-H., Lin, Y., Xue, L., Sun, T.-L., Liu, X.-G., Shao, M., Jayne, J. T., and Worsnop, D. R.: Characterization of submicron aerosols at a rural site in Pearl River Delta of China using an Aerodyne High-Resolution Aerosol Mass Spectrometer, 
Atmos. Chem. Phys., 11, 1865-1877, doi:10.5194/acp-11-18652011, 2011.

Huang, X.-F., He, L.-Y., Xue, L., Sun, T.-L., Zeng, L.-W., Gong, Z.-H., Hu, M., and Zhu, T.: Highly time-resolved chemical characterization of atmospheric fine particles during 2010 Shanghai World Expo, Atmos. Chem. Phys., 12, 4897-4907, doi:10.5194/acp-12-4897-2012, 2012.

Huang, X. F., Xue, L., Tian, X. D., Shao, W. W., Sun, T. L., Gong, Z. H., Ju, W. W., Jiang, B., Hu, M., and He, L. Y.: Highly time-resolved carbonaceous aerosol characterization in Yangtze River Delta of China: Composition, mixing state and secondary formation, Atmos. Environ., 64, 200-207, doi:10.1016/j.atmosenv.2012.09.059, 2013.

Huffman, J. A., Docherty, K. S., Aiken, A. C., Cubison, M. J., Ulbrich, I. M., DeCarlo, P. F., Sueper, D., Jayne, J. T., Worsnop, D. R., Ziemann, P. J., and Jimenez, J. L.: Chemically-resolved aerosol volatility measurements from two megacity field studies, Atmos. Chem. Phys., 9, 7161-7182, doi:10.5194/acp-9-71612009, 2009.

IPCC: Climate Change 2013: The Physical Scientific Basis, Cambridge University Press, Cambridge, England, 622-623, 2013.

Jimenez, J. L., Canagaratna, M. R., Donahue, N. M., Prevot, A. S. H., Zhang, Q., Kroll, J. H., DeCarlo, P. F., Allan, J. D., Coe, H., Ng, N. L., Aiken, A. C., Docherty, K. S., Ulbrich, I. M., Grieshop, A. P., Robinson, A. L., Duplissy, J., Smith, J. D., Wilson, K. R., Lanz, V. A., Hueglin, C., Sun, Y. L., Tian, J., Laaksonen, A., Raatikainen, T., Rautiainen, J., Vaattovaara, P., Ehn, M., Kulmala, M., Tomlinson, J. M., Collins, D. R., Cubison, M. J., Dunlea, E. J., Huffman, J. A., Onasch, T. B., Alfarra, M. R., Williams, P. I., Bower, K., Kondo, Y., Schneider, J., Drewnick, F., Borrmann, S., Weimer, S., Demerjian, K., Salcedo, D., Cottrell, L., Griffin, R., Takami, A., Miyoshi, T., Hatakeyama, S., Shimono, A., Sun, J. Y., Zhang, Y. M., Dzepina, K., Kimmel, J. R., Sueper, D., Jayne, J. T., Herndon, S. C., Trimborn, A. M., Williams, L. R., Wood, E. C., Middlebrook, A. M., Kolb, C. E., Baltensperger, U., and Worsnop, D. R.: Evolution of Organic Aerosols in the Atmosphere, Science, 326, 1525-1529, doi:10.1126/science.1180353, 2009.

Kiss, G., Varga, B., Galambos, I., and Ganszky, I.: Characterization of water-soluble organic matter isolated from atmospheric fine aerosol, J. Geophys. Res.-Atmos., 107, ICC 1-1-ICC 1-8, 2002.

Krivacsy, Z., Gelencser, A., Kiss, G., Meszaros, E., Molnar, A., Hoffer, A., Meszaros, T., Sarvari, Z., Temesi, D., and Varga, B.: Study on the chemical character of water soluble organic compounds in fine atmospheric aerosol at the Jungfraujoch, J. Atmos.Chem., 39, 235-259, 2001.

Kroll, J. H., Donahue, N. M., Jimenez, J. L., Kessler, S. H., Canagaratna, M. R., Wilson, K. R., Altieri, K. E., Mazzoleni, L. R., Wozniak, A. S., Bluhm, H., Mysak, E. R., Smith, J. D., Kolb, C. E., and Worsnop, D. R.: Carbon Oxidation State as a Metric for Describing the Chemistry of Atmospheric Organic Aerosol, Nature Chemistry, 3, 133-139, 2011.

Lanz, V. A., Alfarra, M. R., Baltensperger, U., Buchmann, B., Hueglin, C., and Prévôt, A. S. H.: Source apportionment of submicron organic aerosols at an urban site by factor analytical modelling of aerosol mass spectra, Atmos. Chem. Phys., 7, 15031522, doi:10.5194/acp-7-1503-2007, 2007.

Lee, A. K. Y., Herckes, P., Leaitch, W. R., Macdonald, A. M., and Abbatt, J. P. D.: Aqueous OH oxidation of ambi- ent organic aerosol and cloud water organics: Formation of highly oxidized products, Geophys. Res. Lett., 38, L11805, doi:10.1029/2011GL047439, 2011.

Leone, S. R., Ahmed, M., and Wilson, K. R.: Chemical dynamics, molecular energetics, and kinetics at the synchrotron, Phys. Chem. Chem. Phys., 12, 6564-6578, 2010.

Lin, Y.-H., Zhang, Z., Docherty, K. S., Zhang, H., Budisulistiorini, S. H., Rubitschun, C. L., Shaw, S. L., Knipping, E. M., Edgerton, E. S., and Kleindienst, T. E.: Isoprene epoxydiols as precursors to secondary organic aerosol formation: acid-catalyzed reactive uptake studies with authentic compounds, Environ. Sci. Technol., 46, 250-258, 2012.

Lloyd, J. A. and Johnston, M. V.: An IT-TOF mass spectrometer for the analysis of organic aerosol, Int. J. Mass Spectrom., 281, 8-14, 2009.

Lopez-Hilfiker, F. D., Mohr, C., Ehn, M., Rubach, F., Kleist, E., Wildt, J., Mentel, Th. F., Lutz, A., Hallquist, M., Worsnop, D., and Thornton, J. A.: A novel method for online analysis of gas and particle composition: description and evaluation of a Filter Inlet for Gases and AEROsols (FIGAERO), Atmos. Meas. Tech., 7, 983-1001, doi:10.5194/amt-7-983-2014, 2014.

Martin, S. T., Rosenoern, T., Chen, Q., and Collins, D. R.: Phase changes of ambient particles in the Southern Great Plains of Oklahoma, Geophys. Res. Lett., 35, L22801, doi:10.1029/2008g1035650, 2008.

Mazzoleni, L. R., Ehrmann, B. M., Shen, X. H., Marshall, A. G., and Collett, J. L.: Water-soluble atmospheric organic matter in fog: exact masses and chemicalformula identification by ultrahigh-resolution Fourier transform ion cyclotron resonance mass spectrometry, Environ. Sci. Technol., 44, 3690-3697, 2010.

McLafferty, F. W., and Turecek, F.: Interpretation of Mass Spectra, 248-249, 1993.

Mensah, A. A., Buchholz, A., Mentel, T. F., Tillmann, R., and Kiendler-Scharr, A.: Aerosol mass spectrometric measurements of stable crystal hydrates of oxalates and inferred relative ionization efficiency of water, J. Aerosol Sci., 42, 11-19, 2011.

Mohr, C., DeCarlo, P. F., Heringa, M. F., Chirico, R., Slowik, J. G., Richter, R., Reche, C., Alastuey, A., Querol, X., Seco, R., Peõuelas, J., Jiménez, J. L., Crippa, M., Zimmermann, R., Baltensperger, U., and Prévôt, A. S. H.: Identification and quantification of organic aerosol from cooking and other sources in Barcelona using aerosol mass spectrometer data, Atmos. Chem. Phys., 12, 1649-1665, doi:10.5194/acp-12-1649-2012, 2012.

Moldoveanu, S.: Pyrolysis of Organic Molecules: Applications to Health and Environmental Issues, Elsevier Science, 7-19, 2009.

Mysak, E. R., Smith, J. D., Ashby, P. D., Newberg, J. T., Wilson, K. R., and Bluhm, H.: Competitive reaction pathways for functionalization and volatilization in the heterogeneous oxidation of coronene thin films by hydroxyl radicals and ozone, Phys. Chem. Chem. Phys., 13, 7554-7564, 2011.

Nakao, S., Tang, P., Tang, X., Clark, C. H., Seo, Li. Q., E., AsaAwuku, A., and Cocker III, D.: Density and Elemental Ratios of Secondary Organic Aerosol: Application of a Density Prediction Method., Atmos. Environ., 68, 273-277, 2013.

Ng, N. L., Canagaratna, M. R., Jimenez, J. L., Zhang, Q., Ulbrich, I. M., and Worsnop, D. R.: Real-time methods for estimating organic component mass concentrations from aerosol mass spectrometer data, Environ. Sci. Technol., 45, 910-916, 2010a. 
Ng, N. L., Canagaratna, M. R., Zhang, Q., Jimenez, J. L., Tian, J., Ulbrich, I. M., Kroll, J. H., Docherty, K. S., Chhabra, P. S., Bahreini, R., Murphy, S. M., Seinfeld, J. H., Hildebrandt, L., Donahue, N. M., DeCarlo, P. F., Lanz, V. A., Prévôt, A. S. H., Dinar, E., Rudich, Y., and Worsnop, D. R.: Organic aerosol components observed in Northern Hemispheric datasets from Aerosol Mass Spectrometry, Atmos. Chem. Phys., 10, 46254641, doi:10.5194/acp-10-4625-2010, 2010b.

Ng, N. L., Canagaratna, M. R., Jimenez, J. L., Chhabra, P. S., Seinfeld, J. H., and Worsnop, D. R.: Changes in organic aerosol composition with aging inferred from aerosol mass spectra, Atmos. Chem. Phys., 11, 6465-6474, doi:10.5194/acp-11-64652011, 2011.

Nguyen, H. P. and Schug, K. A.: The advantages of ESI-MS detection in conjunction with HILIC mode separations: Fundamentals and applications, J. Sep. Sci., 31, 1465-1480, 2008.

Northway, M. J., Jayne, J. T., Toohey, D. W., Canagaratna, M. R., Trimborn, A., Akiyama, K.-I., Shimono, A., Jiménez, J. L., DeCarlo, P. F., Wilson, K. R., and Worsnop, D. R.: Demonstration of a VUV lamp photoionization source for improved organic speciation in an aerosol mass spectrometer, Aerosol Sci. and Technol., 41, 829-839, 2007.

O'Brien, R. J., Holmes, J. R., and Bockian, A. H.: Formation of photochemical aerosol from hydrocarbons. Chemical reactivity and products, Environ. Sci. Technol., 9, 568-576, 1975.

Ovadnevaite, J., O'Dowd, C., Dall'Osto, M., Ceburnis, D., Worsnop, D. R., and Berresheim, H.: Detecting high contributions of primary organic matter to marine aerosol: A case study, Geophys. Res. Lett., 38, L02807, doi:10.1029/2010g1046083, 2011

Polidori, A., Turpin, B. J., Davidson, C. I., Rodenburg, L. A., and Maimone, F.: Organic PM 2.5: Fractionation by polarity, FTIR spectroscopy, and OM/OC ratio for the Pittsburgh aerosol, Aerosol Sci. Tech., 42, 233-246, 2008.

Pope, C. A. and Dockery, D. W.: Health effects of fine particulate air pollution: lines that connect., J. Air Waste Manag. Assoc., 56, 709-742, 2006.

Poulain, L., Spindler, G., Birmili, W., Plass-Dülmer, C., Wiedensohler, A., and Herrmann, H.: Seasonal and diurnal variations of particulate nitrate and organic matter at the IfT research station Melpitz, Atmos. Chem. Phys., 11, 12579-12599, doi:10.5194/acp-11-12579-2011, 2011.

Robinson, N. H., Hamilton, J. F., Allan, J. D., Langford, B., Oram, D. E., Chen, Q., Docherty, K., Farmer, D. K., Jimenez, J. L., Ward, M. W., Hewitt, C. N., Barley, M. H., Jenkin, M. E., Rickard, A. R., Martin, S. T., McFiggans, G., and Coe, H.: Evidence for a significant proportion of Secondary Organic Aerosol from isoprene above a maritime tropical forest, Atmos. Chem. Phys., 11, 1039-1050, doi:10.5194/acp-11-1039-2011, 2011.

Saarikoski, S., Carbone, S., Decesari, S., Giulianelli, L., Angelini, F., Canagaratna, M., Ng, N. L., Trimborn, A., Facchini, M. C., Fuzzi, S., Hillamo, R., and Worsnop, D.: Chemical characterization of springtime submicrometer aerosol in Po Valley, Italy, Atmos. Chem. Phys., 12, 8401-8421, doi:10.5194/acp-12-84012012, 2012.

Setyan, A., Zhang, Q., Merkel, M., Knighton, W. B., Sun, Y., Song, C., Shilling, J. E., Onasch, T. B., Herndon, S. C., Worsnop, D. R., Fast, J. D., Zaveri, R. A., Berg, L. K., Wiedensohler, A., Flowers, B. A., Dubey, M. K., and Subramanian, R.: Characterization of submicron particles influenced by mixed biogenic and anthropogenic emissions using high-resolution aerosol mass spectrometry: results from CARES, Atmos. Chem. Phys., 12, 8131-8156, doi:10.5194/acp-12-8131-2012, 2012.

Smith, J. D., Kroll, J. H., Cappa, C. D., Che, D. L., Liu, C. L., Ahmed, M., Leone, S. R., Worsnop, D. R., and Wilson, K. R.: The heterogeneous reaction of hydroxyl radicals with submicron squalane particles: a model system for understanding the oxidative aging of ambient aerosols, Atmos. Chem. Phys., 9, 3209-3222, doi:10.5194/acp-9-3209-2009, 2009.

Sun, Y., Zhang, Q., Macdonald, A. M., Hayden, K., Li, S. M., Liggio, J., Liu, P. S. K., Anlauf, K. G., Leaitch, W. R., Steffen, A., Cubison, M., Worsnop, D. R., van Donkelaar, A., and Martin, R. V.: Size-resolved aerosol chemistry on Whistler Mountain, Canada with a high-resolution aerosol mass spectrometer during INTEX-B, Atmos. Chem. Phys., 9, 3095-3111, doi:10.5194/acp9-3095-2009, 2009.

Sun, Y.-L., Zhang, Q., Schwab, J. J., Demerjian, K. L., Chen, W.N., Bae, M.-S., Hung, H.-M., Hogrefe, O., Frank, B., Rattigan, O. V., and Lin, Y.-C.: Characterization of the sources and processes of organic and inorganic aerosols in New York city with a high-resolution time-of-flight aerosol mass apectrometer, Atmos. Chem. Phys., 11, 1581-1602, doi:10.5194/acp-11-15812011, 2011.

Surratt, J. D., Murphy, S. M., Kroll, J. H., Ng, N. L., Hildebrandt, L., Sorooshian, A., Szmigielski, R., Vermeylen, R., Maenhaut, W., Claeys, M., Flagan, R. C., and Seinfeld, J. H.: Chemical Composition of Secondary Organic Aerosol Formed from the Photooxidation of Isoprene, The Journal of Physical Chemistry A, 110 , 9665-9690, 2006.

Takegawa, N., Miyakawa, T., Kawamura, K., and Kondo, Y.: Contribution of selected dicarboxylic and oxocarboxylic acids in ambient aerosol to the m/z 44 signal of an Aerodyne Aerosol Mass Spectrometer, Aerosol Sci. Tech., 41, 418-437, 2007.

Turpin, B. J. and Lim, H.-J.: Species contributions to $\mathrm{PM}_{2.5}$ mass concentrations: Revisiting common assumptions for estimating organic mass, Aerosol Sci. Tech., 35, 602-610, 2001.

Ulbrich, I. M., Canagaratna, M. R., Zhang, Q., Worsnop, D. R., and Jimenez, J. L.: Interpretation of organic components from Positive Matrix Factorization of aerosol mass spectrometric data, Atmos. Chem. Phys., 9, 2891-2918, doi:10.5194/acp-9-2891-2009, 2009.

Wang, X. F., Gao, S., Yang, X., Chen, H., Chen, J. M., Zhuang, G. S., Surratt, J. D., Chan, M. N., and Seinfeld, J. H.: Evidence for High Molecular Weight Nitrogen-Containing Organic Salts in Urban Aerosols, Environ. Sci. Technol., 44, 4441-4446, doi:10.1021/es1001117, 2010.

Williams, B., Goldstein, A., Kreisberg, N., and Hering, S.: An In-Situ Instrument for Speciated Organic Composition of Atmospheric Aerosols: Thermal Desorption Aerosol Gc/MS-FID (TAG), Aerosol Sci. Technol., 40, 627-638, 2006.

Williams, B. J., Jayne, J. T., Lambe, A. T., Hohaus, T., Kimmel, J. R., Sueper, D., Brooks, W., Williams, L. R., Trimborn, A. M., Hayes, P. L., Jimenez, J. L., Kreisberg, N. M., Hering, S. V., Worton, D. R., Goldstein, A. H., and Worsnop, D. R.: The First Combined Thermal Desorption Aerosol Gas Chromatograph Aerosol Mass Spectrometer (TAG-AMS), Aerosol Sci. Tech., 48, 358-370, doi:10.1080/02786826.2013.875114, 2014. 
Yatavelli, R. L. N. and Thornton, J. A.: Particulate organic matter detection using a micro-orifice volatilization impactor coupled to a chemical ionization mass spectrometer (MOVI-CIMS), Aerosol Sci. Technol., 44, 61-74, 2010.

Zhang, Q., Alfarra, M. R., Worsnop, D. R., Allan, J. D., Coe, H., Canagaratna, M. R., and Jiménez, J. L.: Deconvolution and quantification of hydrocarbon-like and oxygenated organic aerosols based on aerosol mass spectrometry, Environ. Sci. and Technol., 39, 4938-4952 doi:4910.1021/es0485681, 2005.
Zhang, Q., Jimenez, J., Canagaratna, M., Ulbrich, I., Ng, N., Worsnop, D., and Sun, Y.: Understanding atmospheric organic aerosols via factor analysis of aerosol mass spectrometry: a review, Anal. Bioanal. Chem., 401, 3045-3067, 2011.

Zhang, Z., Lin, Y.-H., Zhang, H., Surratt, J. D., Ball, L. M., and Gold, A.: Technical Note: Synthesis of isoprene atmospheric oxidation products: isomeric epoxydiols and the rearrangement products cis- and trans-3-methyl-3,4-dihydroxytetrahydrofuran, Atmos. Chem. Phys., 12, 8529-8535, doi:10.5194/acp-12-85292012, 2012. 